\title{
Comparison of black soldier fly larvae pre-treatments and drying techniques on the microbial load and physico-chemical characteristics
}

\author{
L. Saucier ${ }^{1,2^{*}}$ (D) C. M'ballou ${ }^{1,2}$, C. Ratti ${ }^{2,3}$, M.-H. Deschamps ${ }^{1}$, Y. Lebeuf ${ }^{1}$ and G.W. Vandenberg $^{1}$ \\ ${ }^{1}$ Department of Animal Science, Faculty of Agriculture and Food Science, Université Laval, 2425 rue de l'Agriculture, \\ Quebec City, QC, G1V 0A6, Canada; ${ }^{2}$ Institute of Nutrition and Functional Foods, Université Laval, 2440 boul. Hochelaga, \\ Quebec City, QC, G1V 0A6, Canada; ${ }^{3}$ Department of Soil Science and Agri-food Engineering, Université Laval, 2425 rue \\ de l'Agriculture, Quebec City, QC, G1V0A6, Canada; linda.saucier@fsaa.ulaval.ca
}

Received: 7 January 2021 / Accepted: 21 April 2021

(c) 2021 Wageningen Academic Publishers

OPEN ACCESS (c) (i) RESEARCH ARTICLE

\begin{abstract}
Black soldier fly larvae (BSFL) are good candidates for upcycling wet organic residuals. Like other unprocessed raw animal products, BSFL require processing to prevent spoilage and degradation during storage and to facilitate their use as feed ingredients. In this study, hot-air drying and freeze-drying were examined as means to ensure long-term preservation. Pre-treatments of larvae, such as puncturing, blanching (40 s) and scalding (2, 4, 6 and $8 \mathrm{~min}$ ) in boiling water reduced drying times, most likely by affecting the integrity of the wax-coated cuticle that protects the larvae against desiccation. Overall, the larvae dried two to six times faster using hot-air compared to freeze-drying, and larvae pre-treatments were proven to effectively improve drying efficacy. Pre-treating larvae in boiling water followed by a shorter drying time with hot air was effective at reducing primary and secondary oxidation as well as darkening/browning (colour lightness, $L$ * value) compared to the untreated control (rawthawed) larvae. The larvae pre-treatments in boiling water also led to a significant reduction in microbial load (3.21 to $4.83 \mathrm{log}$ ) in the dry product compared to the control. BSFL powder, produced from grinding thawed larvae that were pre-treated for $4 \mathrm{~min}$ in boiling water before being dried in hot air $\left(60^{\circ} \mathrm{C} ; 6 \mathrm{~h}\right)$, had a water activity below 0.4 . This led to a relatively stable product with limited colour changes over a 30-day storage period. These processing treatments also resulted in a product with no detectable Salmonella and Escherichia coli counts ranging from 100 to $1000 \mathrm{cfu} / \mathrm{g}$. Overall, the powdered BSFL product was deemed suitable to incorporate into pelleted feed under the current regulations in Canada.
\end{abstract}

Keywords: blanching, freeze-drying, hot-air drying, insect, scalding

\section{Introduction}

Over the last decade, the concept of insect farming as a sustainable source of food and feed has been extensively reviewed (Baiano, 2020; Rumpold and Schlüter, 2013a,b; Sun-Waterhouse et al., 2016; Valeras, 2019; Van Huis, 2013). The advantage of raising edible insects lies in the ability to produce quality nutrients with high feed conversion efficiency, over short production periods and with a limited footprint. The potential for some insects to be produced on residual organic materials is certainly one of the greatest advantages, as it provides new avenues for waste management (Berggren et al., 2019; Gold et al., 2018; Zurbrügg et al., 2018).
The ability of black soldier fly larvae (BSFL; Hermetia illucens) to upcycle various waste streams has been widely demonstrated (review by Gold et al., 2018; Lalander et $a l ., 2019)$. Given their saprophagous nature, BSFL can be effectively produced on poultry feed, fruit and vegetable waste, milling and brewery side streams, abattoir waste, municipal organic solid waste, human and animal manure, and sludge with relatively short development times (larval stage of 15 to 50 days). At harvest, BSFL contain good quality fatty acids, proteins, and micronutrients at levels that may vary according to the rearing conditions and feeding substrates (Barragán-Fonseca, 2018; Cammack and Tomberlin, 2017; Lalander et al., 2019; Nguyen et al., 2013). 
In Canada, BSFL are primarily produced on pre-consumer fruit and vegetable residues to reduce feed safety risks associated with pathogen growth (Cappellozza et al., 2019). Each insect product must undergo a thorough evaluation of the safety and/or efficacy of its use in the diet of the intended livestock (CFIA, 2019). This includes an evaluation of the physical, chemical and biological risks to the insect itself, the manufacturing process and the final feed ingredients. To date, only whole, dried larvae have received accreditation as a novel feed for fish and poultry in Canada (Minister of Justice Canada, 2021). However, larvae in a powdered form would ease the incorporation into feed.

Considering that organic residue may already contain high microbial loads, that larvae produce their excreta in the environment in which they grow and that they are processed as whole larvae with intact intestinal tracts, the risks of encountering microbiological pathogens in the final product are high (Bruno et al., 2019; De Smet et al., 2018; Gold et al., 2020; Lalander et al., 2019; Shelomi et al., 2020; Tanga et al., 2021; Wynants et al., 2019). Food waste should be stabilised to reduce these risks upstream of production. Moreover, a period of feed withdrawal to allow the gastro-intestinal tract to be purged could be considered, as is done for large farm animals before slaughter. However, at least one study has demonstrated no improvement in larval microbial load as a result of this process (Larouche, 2019) and can alter gut microbiome (Yang et al., 2021). In all cases, the nutrient composition, near-neutral pH (7.5 \pm 0.2 ; Larouche et al., 2019) and high microbial load contribute to the perishable nature of raw insects and further processing is necessary to stabilise products (Grabowski and Klein, 2017; MelgarLalanne et al., 2019; Sun-Waterhouse et al., 2016; Zhen et al., 2020). Processing techniques must be cost effective for producers and significantly reduce microbiological risks during prolonged storage, all while maintaining nutrient integrity and quality.

Drying (such as roasting, frying, sun-drying, freeze-drying and microwave-assisted drying) is a commonly used technique for increasing the shelf-life of edible insects (Melgar-Lalanne et al., 2019). Oven-drying and freezedrying are the preferred methods for dehydrating whole edible insects (Melgar-Lalanne et al., 2019). In general, oven (convective) drying is most commonly used since it is the least expensive among the more efficient drying processes, and in addition, it can be easily adapted to continuous industrial operations. Conversely, when the quality of the dried product is prioritised, freeze-drying is most often used, despite it being costly and requiring batch processing (Ratti, 2001). Drying reduces the water activity $\left(\mathrm{a}_{\mathrm{w}}\right)$ in feedstuff, which protects against degradative reactions, such as enzymatic reactions, and spoilage from microbiological activity during storage. No microorganisms are able to grow at an $\mathrm{a}_{\mathrm{w}}$ below 0.6 . During the drying process, cells are subjected to osmotic pressure and are exposed to reactive oxygen species that damage macromolecules and membranes as water evaporates (Lang et al., 2016). Despite cell injury, dried goods are not sterile and surviving pathogens are able to grow upon rehydration (Lang et al., 2016). Therefore, blanching prior to drying is a common practice for most commercialised edible insects in order to reduce initial microbial counts and to inactivate enzymes, but would not be severe enough to inactivate bacterial spores (Kamau et al., 2018; Jay, 1992; Larouche et al., 2019; Melgar-Lalanne et al., 2019; Vandeweyer et al., 2017; Zhen et al., 2020).

Hot-air drying results in dehydrated products that can have an extended shelf life of up to a year when stored at room temperature. Unfortunately, these processes often drastically impact the quality of the product affecting attributes such as colour, and leading to component denaturation, compound oxidation, vitamin deterioration, etc. (Larouche et al., 2019; Ratti, 2001). Vacuum freezedrying is the best method for water removal and results in products with the highest quality (due to the absence of oxygen and the low temperatures used during the process), but this dehydration method is expensive (Ratti, 2001). There are a number of recent studies on the drying of insects (mealworm larvae, crickets, BSF) using hot-air drying, microwave drying, freeze-drying and/or fluidisedbed drying, and the impact on the properties of the product (protein quality and functionality, amino acid composition, in vitro digestibility; Huang et al., 2019; Purschke et al., 2018; Vandeweyer et al., 2017; Viera-Alvez et al., 2016). However, to our knowledge, the impact of drying methods on final lipid quality and oxidation has not been previously reported. Understanding the impact on lipid oxidation is important, as it can reduce the nutritional value of the product, negatively affect sensory attributes (Purriños et al., 2011) and produce harmful compounds (Yi et al., 2013) detrimental to the animals that consume the feed/product.

This study reports the impact of larvae pre-treatments (puncture or in boiling water) and drying processes (hotair drying and freeze-drying) on the final BSFL products. Larvae pre-treatments were performed prior to hot-air drying and freeze-drying in order to reduce microbial load, ease water evaporation and ultimately to reduce water activity in the final product to a level that will allow long-term storage while minimising any loss in nutritional value. Impacts on the drying rate, colour and lipid oxidation are also evaluated. The selected processing treatments are expected to effectively reduce the microbial load and contamination levels in BSFL that are intended for consumption as animal feed. 


\section{Material and methods}

\section{Larvae production}

The BSFL used during these experiments were sourced from our colony at the Laboratoire de recherche en sciences aquatiques (LARSA) at Université Laval (Quebec City, QC, Canada). The larvae were produced in 5-l plastic buckets that were incubated in the dark at a constant temperature $\left(27^{\circ} \mathrm{C}\right)$ and relative humidity (80\% RH; MLR-350, Sanyo, Osaka, Japan). For the first four days post-hatching, larvae were fed ad libitum on a diet (50\% wheat bran, $20 \%$ corn meal, 30\% alfalfa meal with water added until a final moisture content of $70 \%$ was reached; Hogsette, 1992) that contained a fungicide $(0.15 \%$ methyl 4-hydroxybenzoate; Sigma-Aldrich, Oakville, ON, Canada; Bruno et al., 2019) to control mould development. On day four, larvae were sieved to adjust density and fed for six days on the Gainesville diet without fungicide at a feeding rate of $100 \mathrm{mg} / \mathrm{larvae} /$ day. On day 10 , larvae $(17.0 \pm 2.2 \mathrm{~mm}$ length, $5.2 \pm 0.3 \mathrm{~mm}$ width, $0.14 \pm 0.03 \mathrm{~g}$ weight) were harvested by immersing in water, sieved and rinsed under running water, followed by rinsing with distilled water. They were then patted dry with absorbent paper and vacuum packaged (Eco Vacuum Pro, Orved S.P.A, Venice, Italy) in polyamide/polyethylene (20/80) channelled vacuum bags (CB100; Orved S.P.A.; total thickness of $100 \mathrm{um} / 3.6 \mathrm{mil}$., $\mathrm{O}_{2}$ transmission rate at $65 \mathrm{~cm}^{3} / \mathrm{m}^{2} \times 24 \mathrm{~h}$ at $23{ }^{\circ} \mathrm{C} / 0 \%$ r.F./RH, water vapour transmission rate at $2.5 \mathrm{~g} / \mathrm{m}^{2} \times 24 \mathrm{~h}$ at $23^{\circ} \mathrm{C} / 85 \% \mathrm{r}$.F./RH). Larvae were then euthanised by freezing and stored at $-40{ }^{\circ} \mathrm{C}$. Hence, raw-thawed larvae were the initial material used for pre-treatments and drying. Fresh larvae were kept on ice until they were vacuum packaged.

\section{Pre-treatment of larvae before drying}

Whole larvae were thawed overnight at $4{ }^{\circ} \mathrm{C}$ in the dark. To facilitate water evaporation through the larval cuticle different pre-treatments were applied. Larvae were punctured (50 $\mu \mathrm{m}$ holes) using a sterile mechanical boring apparatus (Figure S1). Larvae (30-g batches in triplicate) were blanched for $40 \mathrm{~s}$, or scalded for $2,4,6$ or $8 \mathrm{~min}$ in boiling water using a 5-1 vessel equipped with a stainlesssteel perforated sieving basket to remove the larvae instantly. Temperature was monitored to ensure constant water temperature during treatment.

\section{Drying conditions}

Frozen larvae $\left(-40^{\circ} \mathrm{C}\right)$ were hot-air dried (Model UOP8-G, Armfield, Hamsphire, UK) at $60{ }^{\circ} \mathrm{C}$, at an air speed of $1.5 \mathrm{~m} / \mathrm{s}$ and an RH of $30 \%$ for up to $14 \mathrm{~h}$. Freeze-drying (Freeze mobile 251 Vir Tis Company, Gardiner, NY, USA) was performed at a constant shelve temperature $\left(40{ }^{\circ} \mathrm{C}\right)$ under a 0.03 Torr vacuum for up to $72 \mathrm{~h}$. To determine optimal drying conditions, drying curves were determined as described by Caparros Megido et al. (2017). Briefly, drying kinetics were followed by plotting relative water content, $\mathrm{X} / \mathrm{X}_{0}$, over drying time. Dry mass $(\mathrm{D} m)$ was determined using a vacuum oven (Isotemp Vacuum Oven Model 281A, Fisher Scientific, Waltham, MA, USA) in the presence of a desiccant $\left(\mathrm{P}_{2} \mathrm{O}_{5}\right)$ at $60^{\circ} \mathrm{C}$ and 25 Torr for $48 \mathrm{~h}$ (Araya-Farias et al., 2011). Samples were then cooled to room temperature in a desiccator and precisely weighed $( \pm 0.001 \mathrm{~g})$. The $\mathrm{X} / \mathrm{X}_{0}$ ratio was calculated as follows:

$$
\frac{X}{X_{o}}=\frac{\mathrm{W}_{0}-\mathrm{D} m}{\mathrm{~W}_{\mathrm{f}}-\mathrm{D} m}
$$

where $\mathrm{X}$ is the water content of the product after hot-air drying or freeze-drying based on dry basis ( $g$ of water/g of dry mass); $\mathrm{X}_{0}$, water content on dry basis of the initial product; $\mathrm{W}_{0}$ is the weight of the initial product $(\mathrm{g}), \mathrm{W}_{\mathrm{f}}$ is the weight of the product after hot-air drying or freezedrying (g), and Dm is the dry mass, or the final weight of the product after completely dried in a vacuum oven $(\mathrm{g})$.

\section{Quality indicators}

Proximal analyses, lipid oxidation levels and physicochemical characteristics were evaluated for the ground dry larvae and after pre-treatment of larvae and drying by hotair or freeze-drying. After freeze-drying or hot-air drying, larvae were stored overnight in desiccators containing $\mathrm{CaSO}_{4}$ before being ground (Magic Bullet, Model MB1001, Taylorsville, KY, USA), and stored at $-20{ }^{\circ} \mathrm{C}$ until further analysis.

\section{Proximal analysis}

Contents of dry matter (DM) and ash were evaluated in triplicate using procedures AOAC 934.01 and AOAC 942.05, respectively (AOAC, 2016). To determine DM content, DM was first obtained by drying the sample in a vacuum oven at $98{ }^{\circ} \mathrm{C}$ (Vacuum Oven LabLine, model 6273, Thermo Fisher Scientific, Marietta, OH, USA). Ash content was determined by incineration of the DM (Lindberg/ Blue M Box Furnace, model BF51828C-1, Thermo Fisher Scientific, Ashville, NC, USA) at $600{ }^{\circ} \mathrm{C}$ for $13 \mathrm{~h}$.

Total nitrogen content was analysed using the LECO method (Truspec model FP528, Leco Corp., St. Joseph, MO, USA) according to procedure AOAC 992.15 (AOAC, 2016). The protein content was calculated using the nitrogen-toprotein conversion factor $\mathrm{Kp}=4.76$, determined by Janssen $e t$ al. (2017). Protein content is expressed as a percentage (\%) of the dry matter and analyses were performed in triplicate.

To evaluate total lipids, an ether extraction on freezedried ground larvae was performed according to method AOCS AM5-04 from the American Oil Chemists' Society (1998). Extraction was performed with ethyl ether (120 min 
Table 1. Physico-chemical properties of black soldier fly larvae after pre-treatment in boiling water. ${ }^{1}$

\begin{tabular}{|c|c|c|c|c|c|c|}
\hline \multirow[t]{2}{*}{ Parameters $^{2}$} & \multirow[t]{2}{*}{ Raw thawed ${ }^{3}$} & \multirow{2}{*}{$\begin{array}{l}\text { Blanching } \\
40 \mathrm{~s}\end{array}$} & \multicolumn{4}{|l|}{ Scalding } \\
\hline & & & $2 \min$ & $4 \mathrm{~min}$ & $6 \min$ & $8 \mathrm{~min}$ \\
\hline $\mathrm{pH}$ & $6.5 \pm 0.1^{d}$ & $8.6 \pm 0.1^{b}$ & $8.9 \pm 0.1^{a}$ & $8.8 \pm 0.2^{\mathrm{a}}$ & $8.5 \pm 0.1^{c}$ & $8.5 \pm 0.1^{c}$ \\
\hline DM (\%) & $22.1 \pm 0.1^{a}$ & $21.5 \pm 0.4^{a}$ & $21.0 \pm 0.3^{\mathrm{ab}}$ & $20.0 \pm 0.2^{b c}$ & $19.8 \pm 0.1^{c}$ & $18.6 \pm 0.7^{d}$ \\
\hline Ash (\%) & $10.3 \pm 0.1$ & $10.2 \pm 0.1$ & $10.3 \pm 0.3$ & $10.4 \pm 0.3$ & $9.9 \pm 0.7$ & $10.4 \pm 0.3$ \\
\hline $\mathrm{XO}$ (nmol eq. $\mathrm{CHP} / \mathrm{g})$ & $198.4 \pm 30.3$ & $152.0 \pm 5.8$ & $210.4 \pm 39.6$ & $175.0 \pm 36.2$ & $158.2 \pm 53.7$ & $148.6 \pm 15.8$ \\
\hline TBARS (nmol MDA/g) & $58.9 \pm 4.1^{a}$ & $46.0 \pm 3.7^{b}$ & $53.3 \pm 1.5^{\mathrm{ab}}$ & $49.7 \pm 4.9^{b}$ & $46.1 \pm 0.4^{b}$ & $44.5 \pm 2.5^{b}$ \\
\hline$L^{*}$ & $49.2 \pm 0.1^{a}$ & $37.5 \pm 0.4^{b}$ & $31.4 \pm 1.2^{d}$ & $31.5 \pm 0.1^{d}$ & $38.4 \pm 0.1^{b}$ & $33.8 \pm 0.2^{c}$ \\
\hline$a^{*}$ & $3.7 \pm 0.1^{\mathrm{a}}$ & $2.8 \pm 0.1^{b}$ & $1.0 \pm 0.2^{d}$ & $1.7 \pm 0.1^{\mathrm{c}}$ & $1.4 \pm 0.1^{c}$ & $1.4 \pm 0.1^{c}$ \\
\hline$b^{*}$ & $20.1 \pm 0.2^{\mathrm{a}}$ & $13.5 \pm 0.1^{b}$ & $8.00 \pm 0.3^{c}$ & $7.1 \pm 0.1^{d}$ & $8.5 \pm 0.1^{b}$ & $8.3 \pm 0.1 \mathrm{bc}$ \\
\hline$\Delta \mathrm{E}^{4}$ & Reference & $13.1 \pm 0.1^{d}$ & $21.6 \pm 1.1^{\mathrm{a}}$ & $21.9 \pm 0.1^{\mathrm{a}}$ & $15.9 \pm 0.1^{c}$ & $19.4 \pm 0.2^{b}$ \\
\hline$C^{*}$ & $20.2 \pm 0.1^{a}$ & $13.8 \pm 0.1^{b}$ & $8.0 \pm 0.3^{d}$ & $7.3 \pm 0.1^{\mathrm{e}}$ & $8.6 \pm 0.1^{c}$ & $8.4 \pm 0.1^{c}$ \\
\hline $\mathrm{h}^{*}$ & $79.7 \pm 0.1^{b c}$ & $78.4 \pm 0.6^{c}$ & $82.6 \pm 1.5^{a}$ & $76.6 \pm 0.1^{c}$ & $80.7 \pm 0.1^{b}$ & $80.1 \pm 0.1^{b c}$ \\
\hline
\end{tabular}

\footnotetext{
${ }^{1}$ Data represent means \pm standard deviations $(n=6)$. NS $=$ not significant. Values with different letters in the same row are significantly different $(P<0.05)$.

${ }^{2} \mathrm{DM}=$ dry matter; $\mathrm{CHP}=$ cumene hydroperoxide; eq. = equivalent; $\mathrm{MDA}=$ malonaldehyde; TBARS = thiobarbituric acid reactive substances; $\mathrm{XO}=\mathrm{xylenol}$ orange; results are expressed as a percentage (\%) of the dry matter.

${ }^{3}$ Live larvae euthanised by freezing at $-40^{\circ} \mathrm{C}$ and then thawed prior to drying.

${ }^{4} \Delta \mathrm{E}=\left[\left(\mathrm{L}_{\text {ref. }}^{*} \mathrm{~L}_{\text {treated }}^{*}\right)^{2}+\left(\mathrm{a}_{\text {ref }}^{*} \mathrm{a}_{\text {treated }}^{*}\right)^{2}+\left(\mathrm{b}_{\text {ref }}^{*}-\mathrm{b}_{\text {treated }}^{*}\right]^{1 / 2}\right.$ indicates the colour difference using thawed raw-larvae as the reference. Reference larvae were assigned a value of zero. Chroma value $C^{*}=\left(a^{* 2}+b^{* 2}\right)^{1 / 2}$ measures colour intensity. Hue angle $h=\operatorname{Tan}^{-1}\left(b^{*} / a^{*}\right)$ measures colour appearance.
}

at $\left.90{ }^{\circ} \mathrm{C}\right)$ on hydrolysed samples $(4 \mathrm{~N}$ hydrochloric acid, $60 \mathrm{~min}, 90^{\circ} \mathrm{C}$ ) using TX4 filters (XT15 Extractor, ANKOM Technology, New York, NY, USA). Lipid content is expressed as a percentage $(\%)$ of the dry matter and analyses were performed in triplicate.

\section{Lipid oxidation}

Products from primary (hydroperoxides) and secondary oxidation were quantified using a modified version of the Ferrous Oxidation-Xylenol Orange (FOX; Grau et al., 2000; Hermes-Lima et al., 1995) method and the thiobarbituric acid reactive substances (TBARS) method (Joanisse and Storey, 1998; Uchiyama and Mihara, 1978), respectively. The measurements were collected for $3.5 \mathrm{~g}$ of shredded raw-thawed larvae or $1 \mathrm{~g}$ of dry ground larvae. All analyses were performed in triplicate.

For the FOX analyses, samples were homogenised (VDI 25, VWR, Radnor, PA, USA) with 100\% HPLC-grade cold methanol $(1: 5, \mathrm{~m}: \mathrm{v})$ for $45 \mathrm{~s}$ for shredded raw-thawed larvae and $1 \mathrm{~min}$ for dry ground larvae. Homogenates were then centrifuged at $3,000 \times g$, for $10 \mathrm{~min}$ at $4{ }^{\circ} \mathrm{C}$. Next, the supernatant was centrifuged for a second time $(3,000 \times g$, $5 \mathrm{~min}$ at $4{ }^{\circ} \mathrm{C}$ ) and kept on ice in the dark. The reagents were sequentially added and mixed $(250 \mu \mathrm{l}$ of a $1 \mathrm{mM}$ aqueous solution of $\left(\mathrm{NH}_{4}\right)_{2} \mathrm{Fe}\left(\mathrm{SO}_{4}\right)_{2}, 100 \mu \mathrm{l}$ of $25 \mathrm{mM} \mathrm{H}_{2} \mathrm{SO}_{4}$ in methanol, $100 \mu \mathrm{l}$ of $0.1 \mathrm{mM}$ xylenol orange in methanol, 450 $\mu \mathrm{l}$ of methanol and $100 \mu \mathrm{l}$ of the supernatant), and a blank solution was prepared using methanol. Reaction mixtures were incubated in the dark at room temperature $\left(21^{\circ} \mathrm{C}\right)$ for $1 \mathrm{~h}$. Next, the absorbance was measured at $580 \mathrm{~nm}$ against the blank (Varioskan ${ }^{\mathrm{nw}}$, Thermo Electron Corporation, Vantaa, Finland). The quantity of hydroperoxides was evaluated using a standard curve generated from a solution of known concentrations of cumene hydroperoxide (CHP) in methanol. Results are expressed as nmoles of CHP equivalents per $\mathrm{g}$ of dry larvae.

TBARS results are expressed as malondialdehyde (MDA) equivalents (Joanisse and Storey, 1998). Samples were first homogenised in $10 \mathrm{ml}$ of $1.15 \%$ phosphoric acid, centrifuged two times and kept in the dark, as described for the FOX analyses. In glass tubes, $400 \mu \mathrm{l}$ of the supernatant was mixed with $400 \mu \mathrm{l}$ of thiobarbituric acid solution (TBA; $1 \%$ thiobarbiturique acid and $0.1 \mathrm{mM}$ butylated hydroxytoluene in $0.05 \mathrm{M} \mathrm{NaOH}$ ). For the blank solution, $400 \mu \mathrm{l}$ of $3 \mathrm{mM}$ $\mathrm{HCl}$ was used to replace the TBA solution. The standard solution consisted of $400 \mu \mathrm{l}$ of the known concentration of MDA and $400 \mu \mathrm{l}$ of the TBA solution. All the tubes were treated with $200 \mu \mathrm{l}$ of $7 \%$ phosphoric acid before being incubated at $100{ }^{\circ} \mathrm{C}$ for $15 \mathrm{~min}$. After cooling to room temperature in the dark for $10 \mathrm{~min}$, the TBA-aldehyde complex was extracted with $1.5 \mathrm{ml}$ of n-butanol, mixed for $1 \mathrm{~min}$ and centrifuged $\left(2,000 \times g, 5 \mathrm{~min}\right.$ at $\left.4{ }^{\circ} \mathrm{C}\right)$ to separate the organic phase from the aqueous phase. Absorbances of the organic phase were measured at $532 \mathrm{~nm}$ and $600 \mathrm{~nm}$ using a Varioskan spectrophotometer. Changes 
in absorbance $\left(\mathrm{A}_{\mathrm{MDA}}=\mathrm{A}_{532}-\mathrm{A}_{600}\right)$ were used to calculate MDA concentrations. The quantity of MDA was evaluated using a standard curve generated from a solution of $25 \mu \mathrm{M}$ MDA. The results are expressed as nmoles of MDA per $\mathrm{g}$ of dried larvae.

\section{Physico-chemical analysis}

The $\mathrm{pH}$ was measured on a homogenate (VWR, VDI 25 S41, Radnor, PA, USA) of $1 \mathrm{~g}$ of larvae in $10 \mathrm{ml}$ of distilled water using a pH-meter (AB15 pH meter, Accumet BASIC, Thermo Fisher Scientific, Singapore) with an integrated temperature compensation probe (Koniecko, 1984). Also, to evaluate the effectiveness of the drying processes and larval stability in storage, water activity $\left(\mathrm{a}_{\mathrm{w}}\right)$ was determined on $3 \mathrm{~g}$ of ground larvae (Mettler Toledo HR73; AQUA LAB, Guelph, ON, Canada).

The colour of the larvae was measured in triplicate using a chromameter (CR400/410, Konica Minolta Sensing Inc., Osaka, Japan), according to the reflectance coordinates (L*, a*, b*; CIE, 1976) on whole larvae. Colour variation $\left(\Delta \mathrm{E}_{\text {Lab; }}^{*}\right.$ Bußler et al., 2015; Joubran et al., 2015; Purschke et al., 2018) was evaluated using Equation 2, for which raw-thawed larvae were used as the reference for pretreatments, and untreated dry larvae were used as reference for the drying treatments. The colour intensity (chroma, $\left.\mathrm{C}^{*}\right)$ was calculated using Equation 3 and the hue angle (h) was determined by Equation 4 (Hosseinpour et al., 2013):

$$
\begin{aligned}
& \Delta \mathrm{E}=\sqrt{\left(\Delta \mathrm{L}^{*}\right)^{2}+\left(\Delta \mathrm{a}^{*}\right)^{2}+\left(\Delta \mathrm{b}^{*}\right)^{2}} \\
& \mathrm{C}^{*}=\sqrt{\left(\mathrm{a}^{* 2}+\mathrm{b}^{* 2}\right)} \\
& \mathrm{h}=\operatorname{Tan}^{-1}\left(\mathrm{~b}^{*} / \mathrm{a}^{*}\right)
\end{aligned}
$$

\section{Microbial analysis}

Larvae (2 g dried, $25 \mathrm{~g}$ raw-thawed) were diluted (1:10) prior to homogenisation in $0.1 \%(\mathrm{~m} / \mathrm{v})$ peptone water (Bacto peptone, Difco Laboratories, Inc., Detroit, MI, USA). To properly disintegrate live larvae, an autoclavable Waring blender (Conair $^{\text {rx }}$ Waring $^{\text {mit }}$ Laboratory Blenders: Single Speed, Fisher Scientific, Ottawa, ON, Canada; 1 min) with cold peptone water was used. For thawed and dry larvae, homogenisation with a Stomacher (Stomacher ${ }^{\circ} 400 \mathrm{C}$, Seward Laboratory Systems Inc., London, UK) for $1 \mathrm{~min}$ at 230 RPM was sufficient. Then, ten-fold dilutions were carried out in $0.1 \%$ peptone water for enumeration on the appropriate agar plates (Saucier et al., 2000). Total aerobic mesophilic (TAM) counts (MFHPB-18; Health Canada, 2001a) were performed on plate count agar medium (PCA; Difco Laboratories Inc.; $35^{\circ} \mathrm{C}$ for $48 \mathrm{~h}$ ). Presumptive lactic acid bacteria (LAB) were enumerated on de Man, Rogosa and Sharp petri plates (MRS; Difco Laboratories Inc.; $25^{\circ} \mathrm{C}$ for $48 \mathrm{~h}$ ) in anaerobic conditions (GasPak EZ
Anaerobic System, Becton Dickinson [BD], Franklin Lakes, NJ, USA; Saucier et al., 2000). Enterobacteriaceae were enumerated and pour plated with violet red bile glucose agar (VRBG, Difco Laboratories Inc; MFLP-43, Health Canada, 1997), and coliforms were enumerated and pour plated with violet red bile agar (VRBA, Difco Laboratories Inc; MFHPB-31, Health Canada, 2001b) after 24 h of incubation at $37^{\circ} \mathrm{C}$. Escherichia coli counts were determined on $3 \mathrm{M}$ Petrifilm ${ }^{\text {tw }}$ plates (3M Food Safety, London, ON, Canada) using method MFHPB-34 (Health Canada, 2013; $37^{\circ} \mathrm{C}$, 18-24 h). Presumptive Listeria spp. were determined on PALCAM medium (PALCAM Listeria Agars Base; Milipore Sigma, St. Louis, MO, USA) with no supplements, and plates were incubated at $30^{\circ} \mathrm{C}$ for $48 \mathrm{~h}$ (MFHPB-30, Health Canada, 2011). Yeasts and moulds were enumerated on rose bengal agar (Difco Laboratories Inc.) supplemented with $0.01 \%$ chloramphenicol, prepared in $95 \%$ ethanol (Xi'an Henrikang Biotech Co., Ltd. GA13183, Shaanxi, China) and incubated at $25^{\circ} \mathrm{C}$ for 7 days (MFHPB-22, Health Canada, 2018). Presumptive Clostridium spp. were enumerated on reinforced clostridial agar (HiMedia Laboratories, Mumbai, India) and incubated at $36{ }^{\circ} \mathrm{C}$ for $48 \mathrm{~h}$ under anaerobiosis. Salmonella spp. were enumerated on selective CHROMagar $^{\mathrm{mw}}$ (CHROMagar, Paris, France) and sent to an external laboratory for detection using Health Canada method MFHPB-20 (2009). Measurements were performed in duplicate. All bacterial counts were transformed to a $\log$ value of colony-forming units per $\mathrm{g}(\log \mathrm{cfu} / \mathrm{g})$ prior to statistical analysis conducted according to Gill (2000). The detection limit was used in the statistical analysis when no colonies were detected. This limit was calculated as the value when only one colony was detected on one of the two duplicate plates or Petrifilms.

\section{Storage stability}

The larvae that were pretreated in boiling water for $4 \mathrm{~min}$ and dried using hot air at $60^{\circ} \mathrm{C}$ for $6 \mathrm{~h}$ were stored (aliquots of $22 \mathrm{~g}$ ) in the dark (incubator model 1320, VWR Manufacturing, Inc., Sheldon, OR, USA) in 10-oz sterile bags (WhirlPak, Nasco, Fort Atkinson, WE, USA) at $21.6 \pm 0.4{ }^{\circ} \mathrm{C}$ for 30 days. On days $0(\mathrm{n}=3), 15(\mathrm{n}=5)$ and $30(n=5)$, microbial analyses were performed as described above. Measurements for $\mathrm{pH}, \mathrm{a}_{\mathrm{w}}$, primary and secondary oxidation and colour parameters were also collected.

\section{Statistical analyses}

A two-way analysis of variance (ANOVA) was conducted on each physico-chemical and microbial parameter to evaluate the interactions between pre-treatments and drying methods. One-way ANOVAs followed by Tukey HSD tests were subsequently performed to compare the impact of larvae pre-treatments on each drying method (hot-air drying, freeze-drying), as well as to evaluate changes in physico-chemical parameters during storage. 
Although the robustness of the tests could be affected by the small number of samples in this study (Zar, 1999), Shapiro and Bartlett's tests were used to assess normality and homogeneity of the variance, respectively, and should thus be interpreted with caution. When required, $\log$ transformations were used for data homogeneity. Experiments and analyses were performed with three or more replicates for each sample and results are expressed as means \pm standard deviations. A value of $P<0.05$ indicated a significant difference and $P<0.10$ indicated a tendency. All analyses were performed using the RStudio, version 1.3.959 software package (RStudio, Boston, MA, USA).

\section{Results}

\section{Physico-chemical and microbial characterisation of BSFL prior to drying}

In order to facilitate the drying process and reduce the initial microbial load, larvae were submitted to different pre-treatments, including puncturing, blanching $(40 \mathrm{~s})$ and scalding in boiling water for 2, 4, 6 or $8 \mathrm{~min}$. The physicochemical properties of BSFL were greatly affected by the pre-treatments, drying, and their combined effects, with all interactions being significant $(P<0.05$; Table $\mathrm{S} 1)$.

Thawed larvae had a near-neutral pH $(6.5 \pm 0.1)$ which became alkaline (above 8 ) after boiling water pre-treatments (Table 1). The largest increases in $\mathrm{pH}$ were observed after scalding for 2 and $4 \mathrm{~min}$, reaching a $\mathrm{pH}$ of $8.9 \pm 0.1$ and $8.8 \pm 0.2$, respectively. Longer periods of pre-treatment in boiling water led to significant reductions in DM, from $22.1 \pm 0.1$ (thawed larvae) to $18.6 \pm 0.7$ ( $8 \mathrm{~min}$ ). However, ash content was not significantly affected by pre-treatment.

The levels of primary lipid oxidation ranged from $148.6 \pm 15.8$ to $210.4 \pm 39.6 \mathrm{nmol}$ eq. $\mathrm{HPC} / \mathrm{g}$, and were not significantly different between larvae pre-treatments. With the exception of the 2-min scalding treatment, levels of secondary lipid oxidation showed significant reductions with longer periods of boiling water pre-treatment $(P=0.001)$. Values for TBARS ranged from $58.9 \pm 4.1$ for raw-thawed larvae to $44.5 \pm 2.5$ for larvae that were scalded for $8 \mathrm{~min}$.

BSFL became darker $(P<0.001)$ after pre-treatments. Levels of lightness $\left(L^{*}\right)$ were least affected by blanching for $40 \mathrm{~s}$ and scalding for $6 \mathrm{~min}$. The positive value for $\mathrm{a}^{*}$ indicates that the colour of raw-thawed larvae is in the red spectrum. The intensity of redness was reduced after pre-treatments. Scalding for $2 \mathrm{~min}$ resulted in the largest reductions in redness compared to the other pre-treatments $(P<0.001)$. The larvae demonstrated the greatest loss in yellowness (b*) after scalding for $4 \mathrm{~min}$. Overall, colour variations were measured using $\Delta \mathrm{E}$, and results indicate that scalding for 2 and 4 min led to the greatest colour difference resulting in brownish-coloured larvae. Blanching for $40 \mathrm{~s}$ affected colour variation $(\Delta \mathrm{E})$ the least. Colour intensity, $\mathrm{C}^{*}$, followed a similar pattern to $\Delta \mathrm{E}$ in being the least affected by blanching for $40 \mathrm{~s}$ and most affected by scalding for 2 and $4 \mathrm{~min}(P<0.001)$. Compared to the control and the other treatments, scalding for $2 \mathrm{~min}$ resulted in the highest hue angle $\left(h^{*} ; P<0.001\right)$, leading to colours that fall within the yellow-green spectrum.

Larvae pre-treatments significantly affected their microbial load $(P<0.001$; Table 22$)$. Larvae were punctured to improve drying efficiency. Puncturing increased the microbial load for all the microbial groups that were tested, with the exception of TAM (Table 2). However, all the increases were less than one log unit and are therefore of little practical value. Microbial loads were greatly reduced with longer periods of pre-treatment in boiling water $(P<0.05)$ for all tested microbial groups. All the scalding treatments yielded microbial load log reductions greater than 1 for all the tested microbial groups, whereas TAM was the only microbial group to achieve a $1-\log$ reduction after $40 \mathrm{~s}$ of blanching (Table 2).

\section{Drying kinetics}

Drying kinetics curves (i.e. X/Xo vs time) are presented in Figure 1 and 2 for hot-air drying and freeze-drying, respectively. These curves show a characteristic decrease in water content over the drying period, i.e. a negative exponential tendency with a marked decrease in water content in the beginning of the process, followed by a decline in the dehydration rate when bound water becomes harder to remove. Towards the end of the drying period, a plateau forms, which indicates an equilibrium in mass transfer between the product and the drying environment.

As expected, Figure 2 shows that freeze-drying kinetics were slow (14-72 $\mathrm{h}$ to complete drying depending on the larval pre-treatment) compared to hot-air drying (4-12 h, Figure 1). Fourteen hours of freeze-drying were required to reach a water content of $0.1 \mathrm{~g}$ water/g DM when larvae were first scalded for $8 \mathrm{~min}$, while more than $72 \mathrm{~h}$ were required for the control samples (no pre-treatment).

Optimal drying times for achieving similar relative water contents were estimated from the drying kinetics curves in Figure 1 and 2. Using these curves, reductions in drying time as a result of pre-treatments were calculated (Table 3). Pre-treatments showed a marked impact on the time required to dry the larvae. For instance, larvae that were scalded for 8 min required just 4 hours to decrease their initial moisture content to $0.1 \mathrm{~g}$ water/g dry mass by hot-air drying, a $66.7 \%$ reduction compared to the time needed for those that did not undergo any pre-treatments (Table 3 ). For freeze-drying, an $80.6 \%$ drying time reduction was achieved after an 8-min scalding pre-treatment. 
Table 2. Microbial counts (log cfu/g) from black soldier fly larvae after pre-treatment in boiling water. ${ }^{1}$

\begin{tabular}{|c|c|c|c|c|c|c|c|c|}
\hline \multirow[t]{3}{*}{ Parameters $^{2}$} & \multirow[t]{2}{*}{ Raw thawed } & \multirow[t]{2}{*}{ Raw thawed } & \multirow[t]{2}{*}{ Punctured } & \multirow{2}{*}{$\begin{array}{l}\text { Blanching } \\
40 \mathrm{~s}\end{array}$} & \multicolumn{4}{|l|}{ Scalding } \\
\hline & & & & & $2 \min$ & $4 \min$ & $6 \mathrm{~min}$ & $8 \mathrm{~min}$ \\
\hline & WB $^{3}$ & $\mathrm{DB}^{3}$ & $\mathrm{DB}$ & DB & DB & $\mathrm{DB}$ & DB & $\mathrm{DB}$ \\
\hline TAM & $8.28 \pm 0.01$ & $8.96 \pm 0.01^{a}$ & $\begin{array}{c}8.38 \pm 0.00^{b} \\
(0.58)\end{array}$ & $\begin{array}{c}7.90 \pm 0.02^{c} \\
(1.06)\end{array}$ & $\begin{array}{c}7.78 \pm 0.01^{d} \\
(1.18)\end{array}$ & $\begin{array}{c}7.27 \pm 0.02^{\mathrm{e}} \\
(1.39)\end{array}$ & $\begin{array}{c}6.92 \pm 0.01^{f} \\
(2.04)\end{array}$ & $\begin{array}{c}6.72 \pm 0.05^{g} \\
(2.24)\end{array}$ \\
\hline$L A B$ & $7.71 \pm 0.15$ & $8.23 \pm 0.51^{b}$ & $\begin{array}{c}8.47 \pm 0.02^{a} \\
(-0.24)\end{array}$ & $\begin{array}{c}7.56 \pm 0.02^{\mathrm{c}} \\
(0.67)\end{array}$ & $\begin{array}{c}7.07 \pm 0.06^{d} \\
(1.16)\end{array}$ & $\begin{array}{c}6.76 \pm 0.06^{\mathrm{e}} \\
(1.47)\end{array}$ & $\begin{array}{c}5.85 \pm 0.05^{f} \\
(2.38)\end{array}$ & $\begin{array}{c}5.54 \pm 0.06^{9} \\
(2.69)\end{array}$ \\
\hline Enterobacteriacea & $6.60 \pm 0.23$ & $6.92 \pm 0.03^{a}$ & $\begin{array}{c}7.07 \pm 0.02^{\mathrm{a}} \\
(-0.15)\end{array}$ & $\begin{array}{c}6.47 \pm 0.01^{b} \\
(0.45)\end{array}$ & $\begin{array}{c}5.85 \pm 0.02^{\mathrm{c}} \\
(1.07)\end{array}$ & $\begin{array}{c}5.71 \pm 0.03^{\mathrm{c}} \\
(1.21)\end{array}$ & $\begin{array}{c}5.40 \pm 0.09^{d} \\
(1.52)\end{array}$ & $\begin{array}{c}5.30 \pm 0.13^{d} \\
(1.62)\end{array}$ \\
\hline Coliforms & $6.59 \pm 0.26$ & $6.92 \pm 0.04^{b}$ & $\begin{array}{c}7.09 \pm 0.02^{\mathrm{a}} \\
(-0.17)\end{array}$ & $\begin{array}{c}6.45 \pm 0.02^{\mathrm{c}} \\
(0.47)\end{array}$ & $\begin{array}{c}5.89 \pm 0.06^{d} \\
(1.03)\end{array}$ & $\begin{array}{c}5.73 \pm 0.04^{\mathrm{e}} \\
(1.19)\end{array}$ & $\begin{array}{c}5.53 \pm 0.04^{f} \\
(1.39)\end{array}$ & $\begin{array}{c}5.03 \pm 0.049 \\
(1.89)\end{array}$ \\
\hline Listeria spp. & $6.49 \pm 0.07$ & $7.47 \pm 0.03^{b}$ & $\begin{array}{c}7.87 \pm 0.04^{a} \\
(-0.40)\end{array}$ & $\begin{array}{c}6.85 \pm 0.10^{c} \\
(0.62)\end{array}$ & $\begin{array}{c}6.24 \pm 0.07^{d} \\
(1.23)\end{array}$ & $\begin{array}{c}5.85 \pm 0.05^{\mathrm{e}} \\
(1.62)\end{array}$ & $\begin{array}{c}5.54 \pm 0.12^{\mathrm{e}} \\
(1.93)\end{array}$ & $\begin{array}{c}5.67 \pm 0.05^{\mathrm{e}} \\
(1.80)\end{array}$ \\
\hline
\end{tabular}

${ }^{1}$ Data represent means \pm standard deviations $(n=9)$. Data presented in parentheses represent the logarithmic reduction between the raw-thawed larvae and the pre-treated larvae on a dry basis. Values with different letters in the same row are significantly different $(P<0.05)$.

${ }^{2} \mathrm{LAB}=$ lactic acid bacteria; TAM = total aerobic mesophilic counts.

${ }^{3} \mathrm{DB}=$ dry basis; $\mathrm{WB}=$ wet basis. Results are expressed on a dry basis in order to take into account the concentration effect of drying. Multiple comparisons were therefore performed with values expressed as a percentage $(\%)$ of the dry matter (DB).

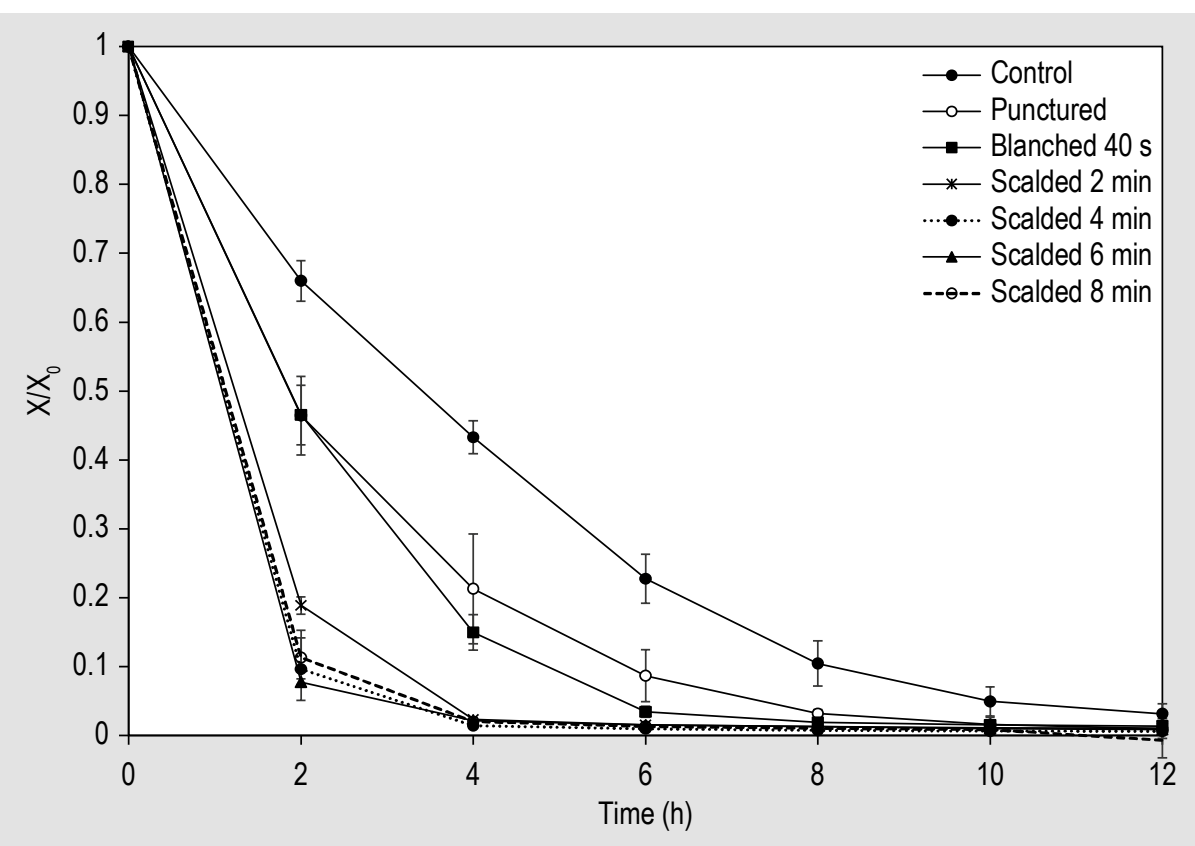

Figure 1. Kinetics curves for hot-air drying $\left(60^{\circ} \mathrm{C}\right)$ black soldier fly larvae after different pre-treatments. Drying experiments were done in triplicate $(n=3)$.

Overall, puncturing the surface of larvae or treating the samples in boiling water accelerated the drying process. With hot-air drying, a 16 to $66 \%$ drying reduction time was observed. A 66 to $80 \%$ reduction was observed from
8 min of scalding prior to hot-air drying and freeze-drying, respectively (Table 3). These results indicate that the larvae pre-treatments facilitate water loss during BSFL drying. 


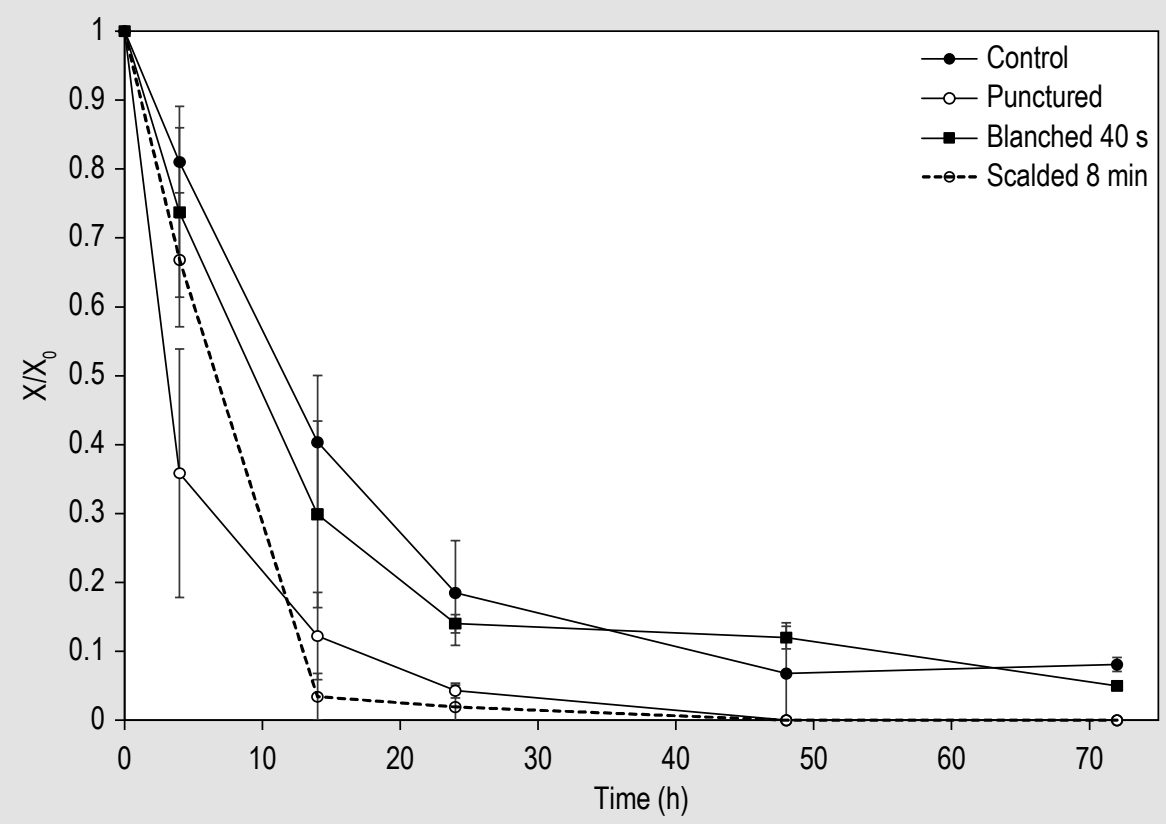

Figure 2. Kinetics curves for freeze-drying $\left(40^{\circ} \mathrm{C}\right.$ heating plate) black soldier fly larvae after different pre-treatments. Drying experiments were done in triplicate $(n=3)$.

Table 3. Optimal drying times, drying time reductions and final water content.

\begin{tabular}{|c|c|c|c|c|}
\hline \multicolumn{2}{|l|}{ Treatments } & $\begin{array}{l}\text { Drying } \\
\text { times (h) }\end{array}$ & $\begin{array}{l}\text { Drying time } \\
\text { reductions (\%) }\end{array}$ & $\begin{array}{l}\text { Relative water } \\
\text { content, } \mathrm{X} / \mathrm{X}_{0}\end{array}$ \\
\hline \multicolumn{5}{|l|}{ Hot-air drying } \\
\hline Control $^{1}$ & & 12 & --- & 0.03 \\
\hline Punctured & & 10 & 16.7 & 0.02 \\
\hline Blanched & $40 \mathrm{~s}$ & 8 & 33.3 & 0.02 \\
\hline \multirow[t]{4}{*}{ Scalded } & $2 \min$ & 6 & 50.0 & 0.02 \\
\hline & $4 \mathrm{~min}$ & 6 & 50.0 & 0.02 \\
\hline & $6 \mathrm{~min}$ & 6 & 50.0 & 0.02 \\
\hline & $8 \mathrm{~min}$ & 4 & 66.7 & 0.01 \\
\hline \multicolumn{5}{|c|}{ Freeze-drying } \\
\hline Control $^{1}$ & & 72 & --- & 0.05 \\
\hline Punctured & & 24 & 66.7 & 0.03 \\
\hline Blanched & $40 \mathrm{~s}$ & 48 & 33.3 & 0.03 \\
\hline Scalded & $8 \mathrm{~min}$ & 14 & 80.6 & 0.03 \\
\hline
\end{tabular}

\section{Physico-chemical and microbial characterisation of dried BSFL}

Physico-chemical properties of hot-air dried larvae are presented in Table 4 and those for freeze-dried larvae are presented in Table 5 . Water activity varied from 0.24 to 0.37 and 0.26 to 0.37 for hot-air and freeze-dried larvae, respectively, suggesting that water removal was efficient for all cases. The DM content was above $90 \%$ for all larvae that were pre-treated with boiling water and subsequently dried using either drying method. The DM content was less than or close to $90 \%$ for the raw-thawed or punctured and dried larvae. Based on the DM content, puncturing improves drying performance when using freeze-drying, but not when using hot air.

When larvae were dried with hot air, the ash content decreased significantly when scalding pre-treatments were $\geq 4 \mathrm{~min}$. However, when larvae were freeze-dried, the ash content was the highest for blanched dried larvae and the lowest for the raw-thawed dried larvae. Hot-air drying resulted in the lowest protein content for larvae that underwent 4 min of scalding, which however, was not significantly different from those that were blanched for $40 \mathrm{~s}(P<0.05)$. Overall, the protein content variation was $\leq 4.6 \%$ for larvae dried with hot air. The protein content for raw-thawed freeze-dried larvae and those scalded for $8 \mathrm{~min}$ were similar, but both groups of larvae had higher protein content compared to those that were punctured and those that were blanched for $40 \mathrm{~s}$ prior to freeze-drying $(P<0.05)$. However, protein content variation was no more than $1.5 \%$ among freeze-dried larvae. The lipid content for hot-air dried larvae was the highest among those that were scalded for $4 \min (29.1 \pm 0.4 \%)$ and the lowest for punctured larvae $(18.7 \pm 2.2 \%)$. Among freeze-dried larvae, those that were punctured also had the lowest lipid content $(18.7 \pm 0.5 \%)$, and the lipid content never exceeded $23.3 \pm 0.1 \%$ for any of the other freeze-dried larvae. 
Among larvae that were dried with hot air, the highest levels of primary oxidation were observed for larvae scalded for $8 \mathrm{~min}(1,934.9 \pm 178.7 \mathrm{nmol} \mathrm{eq}$. CHP/g), followed by raw-thawed and punctured larvae $(1,427.7 \pm 48.1$ and $1,412.7 \pm 103.3 \mathrm{nmol}$ eq. $\mathrm{CHP} / \mathrm{g}$, respectively) and then larvae scalded for $6 \mathrm{~min}(603.9 \pm 41.7 \mathrm{nmol} \mathrm{eq}$. CHP/g). The lowest primary oxidation levels observed were $\leq 488.9 \pm 14.4 \mathrm{nmol}$ eq. $\mathrm{CHP} / \mathrm{g}$ for larvae that were blanched for $40 \mathrm{~s}$ and scalded for 2 and $4 \mathrm{~min}$. These low values are nearly four times lower than the highest level obtained using this drying method (Table 4). Primary oxidation was markedly lower in freeze-dried larvae that were scalded for $8 \mathrm{~min}$. Indeed, primary oxidation was three times lower compared to raw-thawed freeze-dried larvae and two times lower compared to larvae subjected to the two other pre-treatments (Table 4).

Scalding treatments were beneficial for reducing secondary oxidation levels among larvae dried by hot air, compared to the control (Table 4). TBARS values were the lowest among larvae scalded for $4 \mathrm{~min}$ followed by those blanched for $40 \mathrm{~s}$ prior to hot-air drying $(P<0.05)$. With freeze-drying, secondary oxidation levels were not significantly different among treatments $(P>0.05$; Table 5$)$.

Figure 3A presents the lipid oxidation results (TBARS) for some larvae pre-treatments and drying methods. As shown in this figure, 8 min of scalding caused a slight decrease in the oxidation index compared to raw-thawed larvae (44.5 \pm 2.5 compared to $58.9 \pm 4.1 \mathrm{nmol} \mathrm{MDA} / \mathrm{g}$, respectively). However, TBARS levels for the control larvae after hot-air drying increased substantially to $142.2 \pm 3.8 \mathrm{nmol} \mathrm{MDA} / \mathrm{g}$, due to the extended drying time required for non pretreated larvae to reach dryness (12 hours, Table 3 ). This extended drying time allows prolonged contact between the samples and oxygen at $60{ }^{\circ} \mathrm{C}$. Scalding pre-treatment prior to air-drying led to reductions in secondary oxidation in dried larvae, compared to the control (Figure 3A). However, TBARS levels for hot-air dried larvae increased significantly with increasing scalding times during pre-treatment. Thus, longer scalding times may be beneficial for reducing the drying time that is required when using hot air (Table 3). However, depending on the scalding time, pre-treatment in boiling water may also decrease the lipid quality in the dried larvae through oxidation (Figure 3A).

Freeze-dried larvae (control) presents oxidation indexes similar to raw-thawed larvae (Figure 3A) due to the absence of oxygen during freeze-drying under vacuum. The $8-\mathrm{min}$ scalding pre-treatment reduced freeze-drying time by $80.6 \%$ (Table 3) without compromising the lipid quality of the product (Figure 3A).

Larvae pre-treatments in boiling water significantly reduced the darkening effect of hot-air drying (Figure 4). The $\mathrm{L}^{*}$ values for these pre-treated larvae were higher than those for raw-thawed (control) and punctured larvae $(P<0.05)$. Blanching for $40 \mathrm{~s}$ presented the lightest-coloured larvae (Table 4). Among larvae that were freeze-dried, the darkest colours were observed among raw-thawed (control) and 40-s blanched larvae $(P<0.05$; Table 5$)$. As expected, freezedrying had a weaker darkening effect than hot-air drying, as all $L^{*}$ values were higher with freeze-drying than hot-air drying for the same pre-treatments. Punctured dried larvae yielded $L^{*}$ values that were two times greater for freezedrying compared to hot-air drying.

Redness $\left(\mathrm{a}^{*}\right)$ for hot-air dried larvae was the highest among the raw-thawed controls as well as those that were blanched for $40 \mathrm{~s}$ and scalded for 2, 4 and $6 \mathrm{~min}$. The lowest levels of redness were observed in the punctured and 8 -min scalded larvae $(P<0.05$; Table 4$)$. When punctured larvae were freeze-dried, redness was at its lowest, at $1.8 \pm 0.1$. Redness levels were at their highest among rawthawed larvae and 8-min scalded larvae (Table 5). Levels of yellowness $\left(b^{*}\right)$ were highest among hot-air dried larvae that were blanched for $40 \mathrm{~s}$, at $19.1 \pm 0.9$. Yellowness was the lowest among punctured larvae, at 5.2 \pm 0.2 . Scalded larvae exhibited intermediate yellowness, with a greater loss of yellowness as the pre-treatment time in boiling water increased (Table 4). The decrease in yellowness was less marked with freeze-dried larvae, and scalding for $8 \mathrm{~min}$ led to the largest reductions in yellowness (Table 5).

Among the larvae pre-treatments that were tested, puncturing resulted in the least amount of colour change $(\Delta \mathrm{E})$ compared to raw-thawed larvae when subjected to hot-air drying. Among those treated in boiling water, blanching for $40 \mathrm{~s}$ showed the greatest colour change (Table 4). Freeze-dried samples that were blanched for $40 \mathrm{~s}$ showed the least colour change compared to the rawthawed larvae. The greatest colour change was observed in those that were scalded for $8 \mathrm{~min}$ and those that were punctured (Table 5). Larvae that were freeze-dried showed significant reductions in colour intensity $\left(C^{*}\right)$ with increasing pre-treatment severity compared to those that were raw-thawed (control; $P<0.001$ ). Therefore, colour intensity among freeze-dried larvae was at its lowest after scalding for $8 \mathrm{~min}$. Hue angles were similar for all larvae pre-treated in boiling water, and were higher than the rawthawed and punctured hot-air dried larvae (Table 4). For the freeze-dried larvae, hue angles were highest among punctured larvae and the lowest among those that were scalded for $8 \mathrm{~min}$ (Table 5).

Figure 3B shows larval colour changes using the initial colour of raw-thawed untreated larvae as the reference. Colour differences can be classified as a function of $\Delta \mathrm{E}$ values. If $\Delta \mathrm{E}>3$, the colour difference is very visible, $1.5<\Delta \mathrm{E}<3$ means that there is some difference, and $\Delta \mathrm{E}<1.5$ indicates a negligible difference (Adekunte et al., 2010; Purschke et al., 2018). Therefore, as shown in Figure 3B, all 

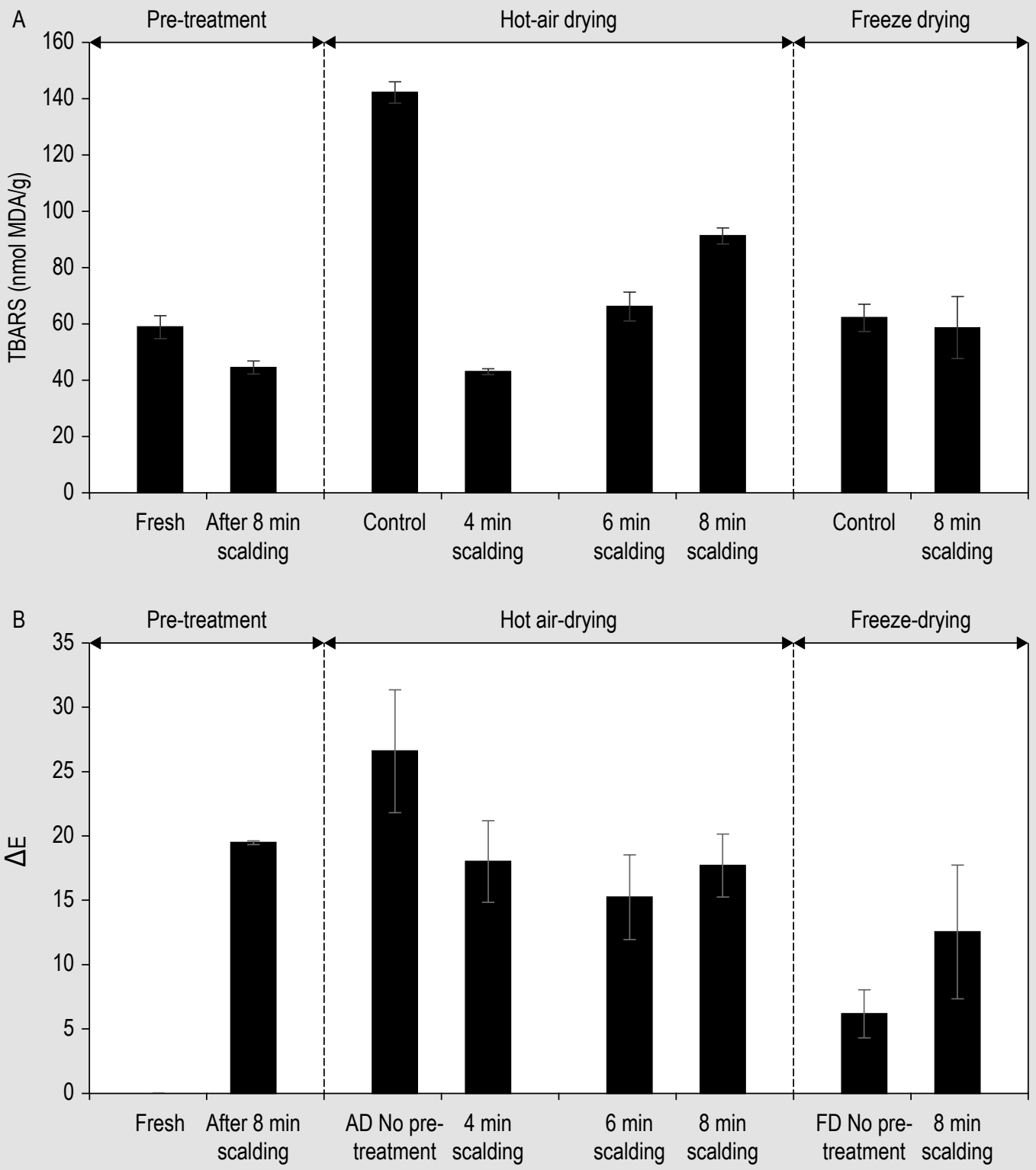

Figure 3. Impact of selected larvae pre-treatments and drying methods on (A) secondary lipid oxidation and (B) colour. The rawthawed larvae were used as the reference for $\Delta E$ calculations. Drying experiments were done in triplicate $(n=3)$.

applied treatments (pre-treatments and drying methods) caused major colour changes in the larvae.

Hot-air drying alone reduced microbial counts by 3.56 to $4.35 \log$ compared with raw-thawed larvae, as presented in Table 6. As expected, microbial counts significantly decreased with increasing scalding times. Log reductions $>4$ were achieved for all cell counts when larvae were pretreated with 6 and 8 min of scalding, compared to those that were raw-thawed. However, larvae pre-treatments appear to have limited beneficial effects on cell counts. Microbial counts that were significantly reduced compared to rawthawed dried larvae required pre-treatment scalding times that were between 4 and $8 \mathrm{~min}$, depending on the microbial type. This was true with the exception of Clostridium spp., yeasts and moulds, for which all pre-treatments were effective in reducing microbial load $(P<0.05)$. A log reduction greater than one, compared to the raw-thawed dried larvae, was only obtained for TAM, LAB and yeasts and moulds.

Freeze-drying also reduced the various microbial counts compared to raw-thawed larvae, but not to the same extent as hot-air drying. Log reductions for the various microbial counts after freeze-drying ranged from 1.29 to 2.69 (Table 7). Larvae pre-treatment in boiling water significantly reduced the microbial counts, while puncturing had little effect compared to raw-thawed freeze-dried larvae. This was the case for all the microbial group tested with the exception of LAB, Listeria spp., E. coli, presumptive Clostridium 


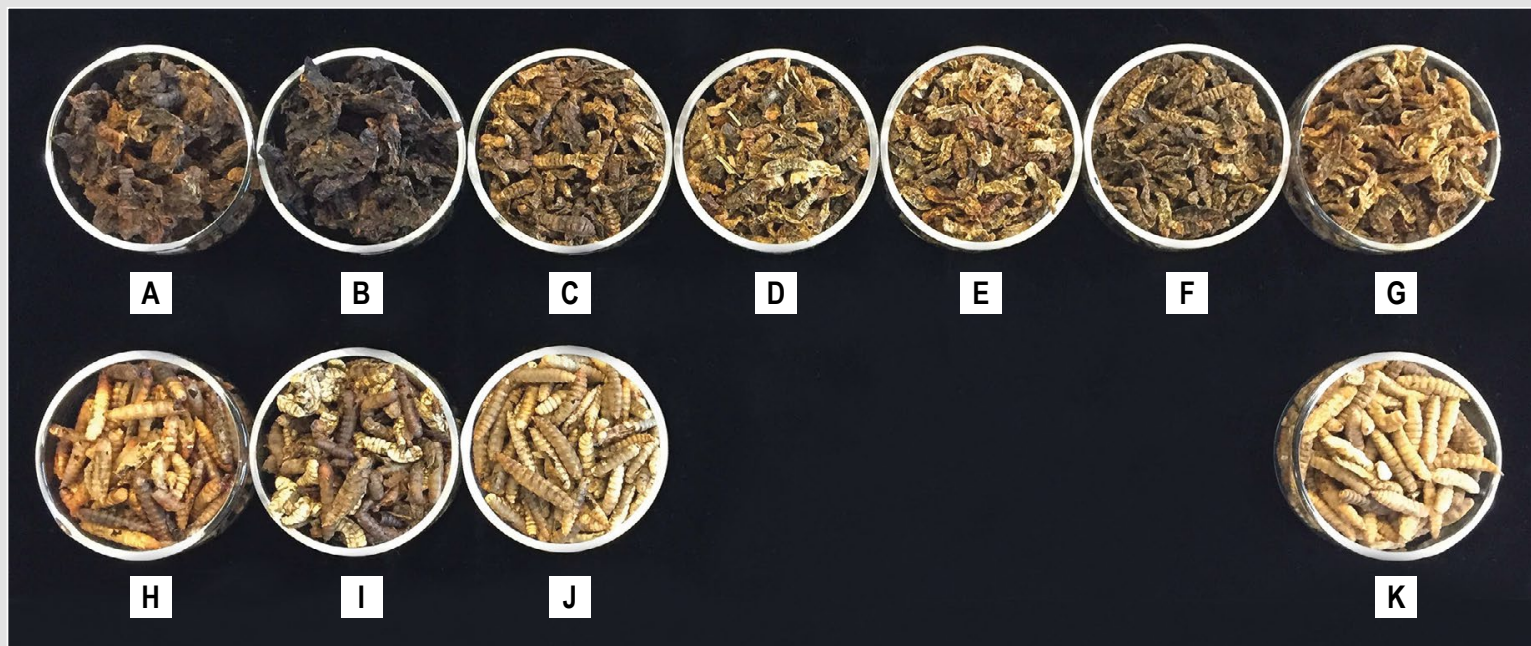

Figure 4. Visual aspect of black soldier fly larvae after pre-treatment followed by hot-air drying $(A=$ raw-thawed dried; $B=$ punctured; $C=$ blanching $40 \mathrm{~s} ; \mathrm{D}, \mathrm{E}, \mathrm{F}$ and $\mathrm{G}=$ scalding for $2,4,6$ and $8 \mathrm{~min}$, respectively) or freeze-drying (H = raw-thawed dried; $\mathrm{I}=$ punctured; $\mathrm{J}$ = blanching $40 \mathrm{~s} ; \mathrm{K}=$ scalding for $8 \mathrm{~min}$ ).

Table 6. Microbial counts (log cfu/g) from black soldier fly larvae after hot-air drying $\left(60^{\circ} \mathrm{C} ; \mathrm{X} / \mathrm{X} 0<0.1\right){ }^{1}$

\begin{tabular}{|c|c|c|c|c|c|c|c|c|}
\hline \multirow[b]{3}{*}{ Parameters $^{2}$} & \multicolumn{8}{|l|}{ After hot-air drying } \\
\hline & \multirow[t]{2}{*}{ Raw thawed, $\mathrm{DB}^{3}$} & \multirow[t]{2}{*}{$\begin{array}{l}\text { Raw thawed } \\
\text { dried, } \mathrm{DB}^{3}\end{array}$} & \multirow[t]{2}{*}{ Punctured DB } & \multirow{2}{*}{$\begin{array}{l}\text { Blanching } \\
40 \mathrm{~s}\end{array}$} & \multicolumn{4}{|l|}{ Scalding } \\
\hline & & & & & $2 \min$ & $4 \min$ & $6 \min$ & $8 \mathrm{~min}$ \\
\hline TAM & $8.95 \pm 0.01$ & $\begin{array}{c}5.39 \pm 0.0^{\mathrm{ab}} \\
(3.56)\end{array}$ & $\begin{array}{c}5.47 \pm 0.00^{\mathrm{a}} \\
(3.48)\end{array}$ & $\begin{array}{c}5.29 \pm 0.01^{\mathrm{ab}} \\
(3.66)\end{array}$ & $\begin{array}{c}5.18 \pm 0.01^{b} \\
(3.77)\end{array}$ & $\begin{array}{c}4.92 \pm 0.01^{\mathrm{c}} \\
(4.00)\end{array}$ & $\begin{array}{c}4.52 \pm 0.02^{\mathrm{d}} \\
(4.43)\end{array}$ & $\begin{array}{c}4.21 \pm 0.08^{\mathrm{e}} \\
(4.74)\end{array}$ \\
\hline LAB & $8.25 \pm 0.03$ & $\begin{array}{c}4.50 \pm 0.12^{\mathrm{ab}} \\
(3.75)\end{array}$ & $\begin{array}{c}4.74 \pm 0.04^{\mathrm{a}} \\
(3.51)\end{array}$ & $\begin{array}{c}4.64 \pm 0.21^{\mathrm{a}} \\
(3.61)\end{array}$ & $\begin{array}{c}4.58 \pm 0.02^{\mathrm{ab}} \\
(3.67)\end{array}$ & $\begin{array}{c}4.35 \pm 0.05^{b c} \\
(3.90)\end{array}$ & $\begin{array}{c}4.12 \pm 0.06^{c} \\
(4.13)\end{array}$ & $\begin{array}{c}3.46 \pm 0.05^{\mathrm{d}} \\
(4.79)\end{array}$ \\
\hline Enterobacteriacea & $6.94 \pm 0.04$ & $\begin{array}{c}3.31 \pm 0.02^{\mathrm{a}} \\
(3.63)\end{array}$ & $\begin{array}{c}3.69 \pm 0.05^{a} \\
(3.25)\end{array}$ & $\begin{array}{c}3.78 \pm 0.01^{\mathrm{a}} \\
(3.16)\end{array}$ & $\begin{array}{c}3.37 \pm 0.01^{\mathrm{ab}} \\
(3.57)\end{array}$ & $\begin{array}{c}3.24 \pm 0.02^{\mathrm{ab}} \\
(3.69)\end{array}$ & $\begin{array}{c}2.83 \pm 0.03^{b} \\
(4.11)\end{array}$ & $\begin{array}{c}2.71 \pm 0.05^{b} \\
(4.23)\end{array}$ \\
\hline Coliforms & $6.92 \pm 0.04$ & $\begin{array}{c}3.25 \pm 0.02^{\mathrm{c}} \\
(3.67)\end{array}$ & $\begin{array}{c}3.52 \pm 0.07^{b} \\
(3.40)\end{array}$ & $\begin{array}{c}3.71 \pm 0.03^{\mathrm{a}} \\
(3.21)\end{array}$ & $\begin{array}{l}3.20 \pm 0.00^{c} \\
(3.72)\end{array}$ & $\begin{array}{c}3.17 \pm 0.01^{\mathrm{c}} \\
(3.75)\end{array}$ & $\begin{array}{c}2.84 \pm 0.05^{\mathrm{d}} \\
(4.08)\end{array}$ & $\begin{array}{c}2.56 \pm 0.08^{\mathrm{e}} \\
(4.36)\end{array}$ \\
\hline Listeria spp. & $7.48 \pm 0.03$ & $\begin{array}{c}3.55 \pm 0.03^{b c} \\
(3.93)\end{array}$ & $\begin{array}{c}4.12 \pm 0.01^{\mathrm{a}} \\
(3.36)\end{array}$ & $\begin{array}{c}4.10 \pm 0.01^{\mathrm{a}} \\
(3.38)\end{array}$ & $\begin{array}{c}3.55 \pm 0.07^{\mathrm{bc}} \\
(3.93)\end{array}$ & $\begin{array}{c}3.64 \pm 0.11^{b} \\
(3.84)\end{array}$ & $\begin{array}{c}3.40 \pm 0.07^{c} \\
(4.08)\end{array}$ & $\begin{array}{c}2.92 \pm 0.03^{\mathrm{d}} \\
(4.56)\end{array}$ \\
\hline Escherichia coli & $7.19 \pm 0.50$ & $\begin{array}{c}2.84 \pm 0.04^{\mathrm{cd}} \\
(4.35)\end{array}$ & $\begin{array}{c}3.49 \pm 0.02^{b} \\
(3.70)\end{array}$ & $\begin{array}{c}3.65 \pm 0.02^{\mathrm{a}} \\
(3.54)\end{array}$ & $\begin{array}{c}3.27 \pm 0.02^{\mathrm{C}} \\
(3.92)\end{array}$ & $\begin{array}{c}2.79 \pm 0.08^{\mathrm{d}} \\
(4.40)\end{array}$ & $\begin{array}{c}2.61 \pm 0.02^{\mathrm{e}} \\
(4.58)\end{array}$ & $\begin{array}{c}2.36 \pm 0.10^{f} \\
(4.83)\end{array}$ \\
\hline Clostridium spp. ${ }^{4}$ & ND & $5.19 \pm 0.01^{a}$ & $5.04 \pm 0.00^{b}$ & $4.88 \pm 0.00^{c}$ & $4.69 \pm 0.01^{d}$ & $4.50 \pm 0.01^{e}$ & $4.30 \pm 0.02^{f}$ & $4.11 \pm 0.02^{\mathrm{g}}$ \\
\hline Yeasts and molds ${ }^{5}$ & ND & $4.83 \pm 0.00^{\mathrm{a}}$ & $4.67 \pm 0.04^{b}$ & $4.46 \pm 0.03^{c}$ & $4.36 \pm 0.03^{c}$ & $4.09 \pm 0.03^{d}$ & $3.41 \pm 0.07^{e}$ & $2.92 \pm 0.07^{f}$ \\
\hline
\end{tabular}


as well as yeasts and moulds, though log variations were all less than 1 . Scalding for $8 \mathrm{~min}$ was the most effective pre-treatment for reducing microbial counts compared to raw-thawed larvae, yielding a reduction of 3.71 to $4.95 \mathrm{log}$. Among the freeze-dried larvae, pre-treatments in boiling water were most efficient for reducing microbial load, with the drying process having only a minor effect.

\section{Storage stability}

The powder obtained from ground BSFL after thawing, scalding for $4 \mathrm{~min}$ and hot-air drying $\left(60^{\circ} \mathrm{C}\right)$ was stored for $30 \mathrm{~d}$ at room temperature to assess it stability. Water activity remained stable over the storage period, but the pH became slightly more acidic by day $30(P<0.05$; Table 8$)$. Primary and secondary oxidation increased significantly over time $(P<0.05)$, while none of the colour parameters changed significantly over time. Nonetheless, $\Delta \mathrm{E}$ values fell between 1.5 and 3 , so colour variations were therefore deemed perceptible. However, the colour variation in samples collected at specific times were similar to those observed between times (data not shown), suggesting a certain level of colour heterogeneity within each sampling time.

Overall, microbial counts decreased significantly $(P<0.05)$ over the storage period except for yeasts and mould. Counts for this group remained at the same levels (Table 9). However, all variations were less than one log unit. Salmonella counts were below the detection level (1.70 $\mathrm{cfu} / \mathrm{g})$ using the selective CHROMagar. The absence of Salmonella was confirmed by an external laboratory using enrichment procedures (Health Canada, 2009).

\section{Discussion}

BSFL are good candidates for upcycling wet residual organic matter and can lead to the reintroduction of valued nutrients into farming systems to raise livestock in a more sustainable manner (Gold et al., 2018; Lalander et al., 2019). The bioconversion of residual organic matter using insects has real potential for future approaches in organic waste management. If properly processed, these insects can be used as a stable feed ingredient.

\section{Drying process}

As expected, our results indicate that whole dry larvae can be obtained faster when hot-air drying is used, compared to freeze-drying (Table 3). The drying process can be 2.5 to 6 times faster, depending on the larvae pre-treatment that is applied. Purschke et al. (2018) studied the dry fractionation of blanched Tenebrio molitor L. larvae. In their study, samples were dehydrated for 24 hours in a convection oven at $60{ }^{\circ} \mathrm{C}$ and for 48 hours, or twice as long, in a freeze-dryer. Although Purschke et al. (2018) did not investigate drying kinetic optimisation, as in this study, their results suggest that freeze-drying times are often longer than air-drying times. Freeze-drying mainly uses the sublimation phenomenon to eliminate most of the water in a product (primary drying). After most of the ice has been sublimated, desorption of non-freezable water occurs (secondary drying). Thus, water loss is first controlled by the progression of a receding sublimation front, leaving a porous dry layer that increases as drying proceeds (Ratti, 2010). A major portion of the bound water is in unfrozen

Table 7. Microbial counts (log cfu/g) from black soldier fly larvae after freeze-drying. ${ }^{1}$

\begin{tabular}{|c|c|c|c|c|c|}
\hline \multirow[t]{2}{*}{ Parameters $^{2}$} & \multicolumn{5}{|l|}{ After freeze-drying } \\
\hline & Raw thawed, $\mathrm{DB}^{3}$ & Raw thawed dried, $\mathrm{DB}^{3}$ & Punctured, DB & Blanching & Scalding \\
\hline & & & & 40 s DB & $8 \min \mathrm{DB}$ \\
\hline TAM & $8.97 \pm 0.01$ & $7.46 \pm 0.00^{\mathrm{a}}(1.51)^{4}$ & $7.47 \pm 0.01^{\mathrm{a}}(1.50)$ & $5.29 \pm 0.01^{b}(3.68)$ & $4.96 \pm 0.01^{\mathrm{c}}(4.01)$ \\
\hline $\mathrm{LAB}$ & $8.26 \pm 0.00$ & $6.97 \pm 0.01^{a}(1.29)$ & $6.72 \pm 0.03^{b}(1.54)$ & $4.58 \pm 0.04^{c}(3.68)$ & $4.55 \pm 0.02^{\mathrm{C}}(3.71)$ \\
\hline Enterobacteriacea & $6.90 \pm 0.01$ & $5.35 \pm 0.05^{\mathrm{a}}(1.55)$ & $5.44 \pm 0.07^{a}(1.46)$ & $3.21 \pm 0.05^{b}(3.69)$ & $3.03 \pm 0.02^{\mathrm{c}}(3.87)$ \\
\hline Coliforms & $6.92 \pm 0.02$ & $5.24 \pm 0.05^{\mathrm{a}}(1.68)$ & $5.33 \pm 0.07^{a}(1.59)$ & $3.11 \pm 0.04^{b}(3.81)$ & $3.03 \pm 0.02^{b}(3.89)$ \\
\hline Listeria spp. & $7.49 \pm 0.04$ & $6.34 \pm 0.01^{a}(1.15)$ & $6.16 \pm 0.03^{b}(1.33)$ & $4.06 \pm 0.06^{c}(3.43)$ & $3.41 \pm 0.06^{\mathrm{d}}(4.08)$ \\
\hline Escherichia coli & $7.86 \pm 0.02$ & $5.17 \pm 0.04^{\mathrm{a}}(2.69)$ & $5.36 \pm 0.02^{b}(2.50)$ & $3.13 \pm 0.02^{c}(4.73)$ & $2.91 \pm 0.03^{\mathrm{d}}(4.95)$ \\
\hline Clostridium spp. ${ }^{4}$ & ND & $5.02 \pm 0.01^{a}$ & $4.95 \pm 0.01^{b}$ & $4.90 \pm 0.01^{\mathrm{c}}$ & $4.20 \pm 0.03^{d}$ \\
\hline Yeasts and moulds & ND & $4.90 \pm 0.01^{a}$ & $4.71 \pm 0.03^{b}$ & $4.49 \pm 0.01^{c}$ & $3.03 \pm 0.05^{d}$ \\
\hline
\end{tabular}


Table 8. Physico-chemical properties of black soldier fly larvae after thawing, scalding for $4 \mathrm{~min}$ and hot-air drying $\left(6 \mathrm{~h}\right.$ at $\left.60^{\circ} \mathrm{C}\right)$ during storage $(30 \mathrm{~d})$ at room temperature $\left(21^{\circ} \mathrm{C}\right) .{ }^{1}$

\begin{tabular}{|c|c|c|c|}
\hline \multirow[t]{2}{*}{ Parameters $^{2}$} & \multicolumn{3}{|l|}{ Storage time } \\
\hline & Day 0 & Day 15 & Day 30 \\
\hline $\mathrm{pH}$ & $7.7 \pm 0.1^{a}$ & $7.6 \pm 0.1^{a}$ & $7.4 \pm 0.1^{b}$ \\
\hline$a_{w}$ & $0.33 \pm 0.00$ & $0.32 \pm 0.00$ & $0.34 \pm 0.01$ \\
\hline XO (nmol eq. CHP/g) & $554.8 \pm 28.2^{\mathrm{a}}$ & $768.4 \pm 45.8^{b}$ & $861.2 \pm 61.1^{c}$ \\
\hline TBARS (nmol MDA/g) & $59.5 \pm 4.3^{a}$ & $66.4 \pm 4.1^{\mathrm{b}}$ & $72.7 \pm 1.3^{c}$ \\
\hline$L^{*}$ & $32.1 \pm 1.3$ & $31.1 \pm 2.7$ & $31.7 \pm 2.1$ \\
\hline$a^{*}$ & $3.5 \pm 0.2$ & $3.6 \pm 0.1$ & $3.3 \pm 0.2$ \\
\hline$b^{*}$ & $13.4 \pm 0.7$ & $13.5 \pm 1.0$ & $12.2 \pm 1.0$ \\
\hline$\Delta \mathrm{E}^{3}$ & Reference & $2.5 \pm 1.7$ & $2.2 \pm 1.3$ \\
\hline$C^{*}$ & $13.9 \pm 0.8$ & $14.1 \pm 1.4$ & $12.7 \pm 1.0$ \\
\hline$h^{*}$ & $75.0 \pm 0.5$ & $75.0 \pm 1.7$ & $74.7 \pm 1.8$ \\
\hline
\end{tabular}

${ }^{1}$ Data represent means \pm standard deviations; $n=3$ on day 0 and $n=5$ on days 15 and 30 . NS $=$ not significant. Values with different letters in the same row are significantly different $(P<0.05)$.

${ }^{2} \mathrm{a}_{\mathrm{w}}=$ water activity, CHP = cumene hydroperoxide; eq. = equivalent; MDA = malonaldehyde; TBARS $=$ thiobarbituric acid reactive substances; $X O=$ xylenol orange; results are expressed as a percentage $(\%)$ of the dry matter.

${ }^{3} \Delta \mathrm{E}=\left[\left(\mathrm{L}_{\text {ref. }}^{*} \mathrm{~L}_{\text {treated }}^{*}\right)^{2}+\left(\mathrm{a}_{\text {ref }}^{*} \mathrm{a}_{\text {treated }}^{*}\right)^{2}+\left(\mathrm{b}_{\text {ref }}^{*}-\mathrm{b}_{\text {treated }}^{*}\right)^{2}\right]^{1 / 2}$ indicates the colour difference using Day 0 as the reference. The reference is assigned a value of zero. Chroma value $C^{*}=\left(a^{* 2}+b^{* 2}\right)^{1 / 2}$ measures colour intensity. Hue angle $h=\operatorname{Tan}^{-1}\left(b^{\star} / a^{*}\right)$ measures colour appearance.

state in this dry layer and the freeze-drying rate becomes very slow during secondary drying (Vega-Mercado et al., 2001). Both primary and secondary drying stages during freeze-drying lead to slower drying kinetics than convective drying, even at a $40{ }^{\circ} \mathrm{C}$ shelf plate.

For both drying methods, larvae pre-treatments were effective in reducing drying times. Drying times were reduced by 16 to $66 \%$ and 66 to $80 \%$ for hot-air and freezedrying, respectively (Table 3). Puncturing holes in the larval cuticle alone provided 16.7 and $66.7 \%$ reductions in drying time for hot-air and freeze-drying, respectively (Table 3). Treating larvae with boiling water for various lengths of time is also likely to damage the cuticle. The cuticle is composed of a thin, outer protein layer called the epicuticle, and a thick, inner, chitin-protein layer called the procuticle (Barnes, 2020). In insects, the external epicuticle structure contains wax (Boevé et al., 2004), which serves as a water-impermeable barrier, protecting larvae against desiccation (Andersen, 2009). Thus, pre-treatments such as puncturing or melting the wax by scalding or directly steaming may facilitate insect larvae drying. Similar observations have been made in berry dehydration, where the waxy cuticle slowed down water loss during drying due to its hydrophobicity (Araya-Farias et al., 2011; Ketata
Table 9. Microbial counts (log cfu/g) from black soldier fly larvae during storage $(30 \mathrm{~d})$ at room temperature $\left(21^{\circ} \mathrm{C}\right)$ after thawing, scalding for 4 min and hot-air drying $\left(6 \mathrm{~h}\right.$ at $\left.60^{\circ} \mathrm{C}\right) .^{1}$

\begin{tabular}{llll} 
Parameters $^{2}$ & \multicolumn{2}{l}{ Storage time } \\
\cline { 2 - 4 } & Day 0 & Day 15 & Day 30 \\
TAM & $4.94 \pm 0.01^{\mathrm{a}}$ & $4.83 \pm 0.02^{\mathrm{b}}$ & $4.80 \pm 0.01^{\mathrm{b}}$ \\
LAB & $4.33 \pm 0.04^{\mathrm{a}}$ & $4.16 \pm 0.08^{\mathrm{b}}$ & $4.06 \pm 0.04^{\mathrm{c}}$ \\
Enterobacteriacea & $3.24 \pm 0.04^{\mathrm{a}}$ & $3.03 \pm 0.03^{\mathrm{b}}$ & $3.05 \pm 0.06^{\mathrm{b}}$ \\
Coliforms & $3.14 \pm 0.02^{\mathrm{a}}$ & $3.08 \pm 0.04^{\mathrm{b}}$ & $3.02 \pm 0.02^{\mathrm{c}}$ \\
Listeria spp. & $3.53 \pm 0.12^{\mathrm{a}}$ & $3.13 \pm 0.13^{\mathrm{b}}$ & $3.09 \pm 0.09^{\mathrm{b}}$ \\
Escherichia coli & $2.83 \pm 0.13^{\mathrm{a}}$ & $2.51 \pm 0.15^{\mathrm{b}}$ & $2.43 \pm 0.13^{\mathrm{b}}$ \\
Clostridium spp. & $4.55 \pm 0.03^{\mathrm{a}}$ & $4.45 \pm 0.07^{\mathrm{ab}}$ & $4.40 \pm 0.04^{\mathrm{b}}$ \\
Yeasts and moulds & $4.03 \pm 0.02$ & $4.04 \pm 0.01$ & $4.05 \pm 0.01$ \\
Salmonella & $\mathrm{BDL} \mathrm{L}^{3}$ & $\mathrm{BDL}$ & $\mathrm{BDL}$ \\
\hline
\end{tabular}

${ }^{1}$ Data represent means \pm standard deviations; $n=3$ on day 0 and $n=5$ on days 15 and 30 . Values with different letters in the same row are significantly different $(P<0.05)$.

${ }^{2} \mathrm{LAB}=$ lactic acid bacteria; TAM = total aerobic mesophilic counts.

${ }^{3} \mathrm{BDL}=$ below detection level $(1.70 \mathrm{log} \mathrm{cfu} / \mathrm{g})$. Absence of Salmonella was confirmed by an external laboratory using method MFHPB-20 from Health Canada (2009)

et al., 2013). Scanning electron microscopy and optical microscopy of berry skins have demonstrated that removing the waxy cuticle layer after pre-treatment facilitated water loss during drying (Ketata et al., 2013).

\section{Microbial load reduction}

Initial microbial load levels for TAM and Enterobacteriacea in the raw-thawed larvae in this study were above the levels reported by Kashiri et al. (2018) and Cappellozza et al. (2019), but below those reported by Larouche et al. (2019) and Wynants et al. (2019) for BSFL raised with different substrates. The larvae in our experiment were punctured as a way to ease water removal during larvae drying. Although this was effective in reducing the drying time, puncturing larvae prior to drying increased the microbial load. All microbial counts were significantly higher for punctured larvae compared to raw-thawed larvae, with the exception of TAM. However, all the log variations were below one and could simply be due to the result of an improved extraction by the puncture of the larvae structure (Table 2). Similarly, and independent of the drying method used, when comparing punctured dried larvae to raw-thawed dried larvae with no pre-treatment, significant differences can be observed among the various microbial groups tested. Notably, E. coli counts increased significantly whereas Clostridium spp. and yeast and moulds decreased significantly. All the significant variations observed, however, were less than $1 \log$ unit (Tables 6 and 7). Any additional 
processing step that does not have an inhibitory effect on the microbiome could potentially introduce contamination. However, a log variation equal to or greater than one is the threshold practical value for the assessment of processing microbial reduction efficacy (Gill, 2000).

The significant interactions observed between larvae pre-treatments and drying methods for all the tested microbial groups, except for yeasts and moulds (Table 3), suggest that microbial reduction varies depending on the drying method used, when the same pre-treatments are applied. Heat treatments are commonly used to reduce microbial populations in food and feed. Their efficacy varies with the method and severity of the treatments, heat transfer parameters of the matrix, and also the intrinsic heat resistance of the different groups of microorganisms present, notably spore formers (Jay, 1992; Nesvadba, 2014). Since pre-treatment in boiling water also facilitates drying while reducing microbial load, this method is preferred over the puncturing method.

As with other product of animal origin, insects carry various pathogens and high bacterial counts can be expected. As a comparison, minced meat and seafood regulations have formed the basis of the primary microbial risk assessment associated with edible insects due to the lack of better available knowledge (Grabowski and Klein, 2017). Future edible insect guidelines and regulations are expected to require the absence of Salmonella and may also recommend levels of TAM, Staphylococcus aureus and E. coli to be below $10^{6}, 10^{3}$ and $10 \mathrm{cfu} / \mathrm{g}$, respectively (MAPAQ, 2019). In our study, even after pre-treating larvae in boiling water and then drying, controlling $E$. coli numbers would require further interventions, whereas the standards for TAM were met (Tables 6 and 7). In our study, Enterobacteriacea counts remained at $5.30 \pm 0.13 \mathrm{log} \mathrm{cfu} / \mathrm{g}$ even after $8 \mathrm{~min}$ of boiling water (Table 2) whereas Larouche et al. (2019) were able to reduce their count to below detection level with blanching 40 s. Surprisingly, Zhen et al. (2020), using also blanching $40 \mathrm{~s}$, obtained high total viable counts $(9.89 \mathrm{log} \mathrm{cfu} / \mathrm{g}$ ) for BSFL raised on fattening broiler chicken diet and palm kernel meal. In other insects, Klunder et al. (2012) were able to efficiently reduce Enterobacteriacea to less than $1 \log$ $\mathrm{cfu} / \mathrm{g}$ by boiling crickets and mealworm larvae in water for a few minutes. Vandeweyer et al. (2017) also observed several microbial log reductions by blanching mealworm larvae for $40 \mathrm{~s}$ followed by microwave drying. Their treatments represented a level of treatment akin to pasteurisation, with little effect on bacterial spores. This suggests that some insects may be more difficult to decontaminate due to their structure, composition and type, as well as level of contamination prior to processing. Fat content is known to reduce heat treatment efficacy (Nesvadba, 2014). High hydrostatic pressure has also been used successfully to reduce microorganisms in BSFL, including E. coli $\mathrm{O} 157: \mathrm{H} 7$ (Kashiri et al., 2018).
BSFL gut microbiota may vary to a certain degree depending on diet (Bruno et al., 2019; Klammsteiner et al., 2020; Tanga et al., 2021; Wynants et al., 2019), and the feed and conditions in which the BSFL are raised are likely to affect the efficacy of the processing procedures for microbial risk mitigation. The initial microbial load of larvae will undoubtedly affect the efficacy of antimicrobial treatments and it is therefore best to keep these numbers as low as possible. In addition, the $\mathrm{pH}$ of larvae went from $6.5 \pm 0.1$ in the raw-thawed state (Table 1 ) to a $\mathrm{pH}>8$ after pre-treatment in boiling water (Table 1) which decreased after drying (7.4-7; Table 8). These results are in agreement with Larouche et al. (2019) where BSF larvae pH is reported at $8.7 \pm 0.1$ and $7.8 \pm 0.5$ after treatment in boiling water and drying, respectively. However, Zhen et al. (2020) obtained a $\mathrm{pH}$ below 8 after blanching treatment of $40 \mathrm{~s}$ suggesting that many factors, which may include raising conditions and diet, influence the reactivity of the larvae matrix. The high $\mathrm{pH}$ $(>8.5)$ after pre-treatment in boiling water are comparable to the alkaline $\mathrm{pH}$ of the albumin (8.0) in freshly-laid chicken eggs, which is known to inhibit microbial growth compared to the yolk, which as a more neutral pH (Heath, 1977). As the $\mathrm{pH}$ becomes less neutral and more acidic or alkaline, the conditions become less favourable for microbial growth, as is the case for E. coli at high pH levels (Geveke, 2008). The increase in $\mathrm{pH}$ observed in BSFL during our study may be due to unfolding imidazolium that leads to histidine basic residue exposure during heating, or a decarboxylation reaction, as is observed in other biological systems (Choi et al., 2009; Marshall and Bal'a, 2001). Further investigation is required to accurately identify the mechanisms that are involved in the $\mathrm{pH}$ increase that occurs after heat treatment with boiling water.

\section{Product quality}

Insects have a high protein content (13-77\% of DM) that varies among insect orders and species, depending on the stage of metamorphosis and feeding substrate (Cammack and Tomberlin, 2017; Cappelloza et al., 2019; Nguyen et al., 2013; Valeras, 2019; Van Huis et al., 2013). In this study, the protein content of the dried larvae varied from $35 \%$ to almost $40 \%$ on a dry basis depending on the larvae pretreatments prior to hot-air and freeze-drying (Tables 4 and 5). Our results are higher than those reported in the review by Nowak et al. (2016), where the average protein concentration (grasshoppers, crickets, flies, butterflies, etc.) was reported to be $17.85 \mathrm{~g} / 100 \mathrm{~g}$ of insects which represents $21 \%$ of DM. However, the results for protein content in this study are similar to those reported by Huang et al. (2019) in their study on BSFL (42.0\% of crude protein in dry basis). The differences in protein content for various scalding times, as shown in Table 4, could be related to the loss of soluble proteins into the boiling water. Indeed, Ursu et al. (2016) showed that the protein content of ham decreased when boiled. In addition, Purschke et al. (2018) 
demonstrated a decrease in the protein content of larvae that were blanched prior to drying ( $65.5 \%$ for oven drying, and $55 \%$ for freeze-drying). Low lipid content values were detected for punctured larvae (Tables 4 and 5). This may be due to lipids that were lost by the contents of the larvae dripping out during subsequent steps.

Puncturing increases oxygen accessibility to constituents and therefore can cause colour change notably by enzymatic or non-enzymatic browning reactions (Zhen et al., 2020) and by conversion of ferrous iron present in BSFL into ferric iron which will react with other constituents (Janssen et al., 2018). Boiling as a pre-treatment prior to air-drying allows for oxidation reduction in dried larvae, compared to the control (Figure 3A). This can be explained by enzyme inactivation, but also by the reduction in drying time (Table 3). Moreover, TBARS levels in air-dried larvae increased significantly with the length of scalding time during pre-treatment (Figure 3A). This may be due to the steady removal of the larval cuticle's wax covering, which acts to protect the larvae against oxidation and other deteriorative activities, as a function of scalding time. Thus, even though longer scalding times might reduce hot-air drying processing times and microbial load, it could also decrease lipid quality in dried larvae through oxidation.

After hot air-drying, dried larvae with no pre-treatment showed the largest colour change (Figure 3B) as well as the largest oxidation levels (Figure 3A). Scalding prior to air-drying helped to minimise colour changes relative to the control dried larvae. This was true for all scalding times with no significant differences between them. The colour changes that were observed could also be explained by larvae light reflection, which is higher in fresh larvae, because of their limited absorption capacity due to the high content of extra cellular water (Faustman et al., 1989).

Of all the treatments examined, freeze-drying resulted in the smallest amount of colour change (with or without pretreatment), reinforcing the connection between oxidation, colour change and drying time. These results are consistent with those from Purschke et al. (2018), which showed that freeze-dried blanched larvae maintained their original colour, while those that were oven-dried at $80^{\circ} \mathrm{C}$ (blanched) exhibited a marked colour change.

Increases in primary and secondary oxidation indicate that other strategies, such as packaging and processing under vacuum should be considered in order to limit lipid degradation and prevent rancidity.

\section{Storage}

For the storage assay, the ground powder from thawed larvae that were scalded for $4 \mathrm{~min}$ and then dried with hot air $\left(60^{\circ} \mathrm{C} ; 6 \mathrm{~h}\right)$ was used because hot-air drying was more effective than freeze-drying (Table 3). Although the microbial load was significantly lower among larvae that were scalded for 6 and $8 \mathrm{~min}$, the log reduction was less than one compared to those that were scalded for 4 min (Table 6). Therefore, there was no need to apply a more severe heat treatment that would negatively affect other parameters, such as lipid oxidation (Table 4). The larvae powder remained relatively stable over the 30-day storage period. When properly closed, WhirlPak bags can limit interaction with air and could contribute to storage stability. Water activity did not vary significantly over time and colour changes were limited. Water activity was between 0.24 and 0.37 (Tables 4 and 5), which is considered effective for the control of microbial growth since it is below 0.6 (Rahman, 2007). Indeed, over the 30-d storage period, microbial counts decreased slightly (less than $1 \mathrm{log}$ reduction) or remained stable (yeasts and moulds; Table 9). Furthermore, water activity was also within the 0.2 to 0.4 range for reduced enzymatic reactions and browning (Rahman, 2007). Lipid oxidation rates were also low (Table 8). However, to meet market demand for a long shelf life for dried products, the experiment will need to be repeated over a longer period of time.

The absence of any detectable Salmonella is an absolute requirement for both animal feed and human food ingredients (CFIA, 2018). This requirement was met with the larvae powder that was used in the storage experiment. Furthermore, the heat treatments during pre-treatment and drying reduced larval $E$. coli counts by more than 4-log unit for larvae scalded 4, 6 or $8 \mathrm{~min}$ (Table 6). One major difficulty, with respect to microbial safety, is the fact that the larvae are raised in close contact with their faecal dejections (Larouche, 2019).

\section{Conclusion}

Despite some challenges, BSFL farming and processing could help provide the animal feed industry with novel, safe and sustainable protein sources. In this study, larvae pre-treatments in boiling water were deemed important as they are effective in reducing the microbial load, drying time and oxidation in the final dry BSFL product. In terms of drying efficacy, hot-air drying should be considered the preferred method, although the final product turns an intense brown colour. This change in colour is not expected to impact its acceptability as feed ingredient. The water activity achieved in the final product $(<0.4)$ was sufficient to provide product stability and, although additional antimicrobial interventions could further improve the final microbial load, the absence of Salmonella suggests that the dried BSFL produced would be fit for use in feed under the current regulations in Canada. 


\section{Supplementary material}

Supplementary material can be found online at https://doi. org/10.3920/JIFF2021.0002.

Figure S1. Device used to puncture larvae.

Table S1. The $P$-values for pre-treatments (P), drying (D) and their interactions on the physico-chemical properties of black soldier fly larvae.

Table S2. The $P$-values for pre-treatments (P), drying (D) and their interactions on the microbial load in black soldier fly larvae.

\section{Acknowledgements}

This research was conducted with financial support from the Programme de soutien à linnovation en agroalimentaire, a program that originated from the Growing Forward agreement between the Ministère de l'agriculture des pêcheries et de l'alimentation du Québec (MAPAQ) and Agriculture and Agri-Food Canada (AAFC). Special thanks to the members of the LARSA and the Groupe de recherche intégré en physiologie et sciences animales (GRIPHA) for their technical support as well as the financial support of the network Ressources Aquatiques Québec and the Canadian Francophonie Scholarship Program.

\section{Conflict of interest}

The authors declare no conflict of interest.

\section{References}

Adekunte, A.O., Tiwari, B.K., Cullen, P.J., Scannell, A.G.M. and O'Donnell, C.P., 2010. Effect of sonication on colour, ascorbic acid and yeast inactivation in tomato juice. Food Chemistry 122(3): 500507. https://doi.org/10.1016/j.foodchem.2010.01.026

American Oil Chemists' Society (AOCS), 1998. Official methods and recommended practices of the American Oil Chemists' Society, $5^{\text {th }}$ edition. AOCS Press, Urbana, IL, USA, 1200 pp.

Andersen, S.O., 2009. Exoskeleton. In: Resh, V.H. and Cardé, R.T. (eds.) Encyclopedia of insects, $2^{\text {nd }}$ edition. Academic Press, Cambridge, MA, USA, pp. 173-221. https://doi.org/10.1016/B978-0-12-3741448.X0001-X

Araya-Farias, M., Makhlouf, J. and Ratti, C., 2011. Drying of seabuckthorn (Hippophae rhamnoides L.) berry: impact of dehydration methods on kinetics and quality. Drying Technology 29(3): 351-359. https://doi.org/10.1080/07373937.2010.497590

Association of Official Analytical Chemists (AOAC), 2016. Official methods of analysis, $20^{\text {th }}$ edition. AOCS, Rockville, MD, USA, 3172 pp.
Baiano, A., 2020. Edible insects: an overview on nutritional characteristics, safety, farming, production technologies, regulatory framework, and socio-economic and ethical implications. Trends in Food Science and Technology 100: 35-50. https://doi.org/10.1016/j. tifs.2020.03.040

Barnes, R.D., 2020. Arthropod. Encyclopædia Britannica, Inc., Chicago, IL, USA. Available at: https://www.britannica.com/ animal/arthropod.

Barragán-Fonseca, K., Pineda-Mejia, J., Dicke, M. and Van Loon, J.J.A., 2018. Performance of the black soldier fly (Diptera: Stratiomyidae) on vegetable residue-based diets formulated based on protein and carbohydrate contents. Journal of Economic Entomology 111: 2676-2683. https://doi.org/10.1093/jee/toy270

Berggren, Å., Jansson, A. and Low, M., 2019. Approaching ecological sustainability in the emerging insects-as-food industry. Trends in Ecology and Evolution 34: 132-138. https://doi.org/10.1016/j. tree.2018.11.005

Boevé, J.L., Ducarme, V., Mertens, T., Bouillard, P. and Angeli, S., 2004. Surface structure, model and mechanism of an insect integument adapted to be damaged easily. Journal of Nanobiotechnology 2(1): 10. https://doi.org/10.1186/1477-3155-2-10

Bruno, D., Bonelli, M., De Filippis, F., Di Lelio, I., Tettamanti, G., Casartelli, M., Ercolini, D. and Caccia, S., 2019. The intestinal microbiota of Hermetia illucens larvae is affected by diet and shows a diverse composition in the different midgut regions. Applied and Environmental Microbiology 85(2): e01864-18. https://doi. org/10.1128/AEM.01864-18

Bußler, S., Steins, V., Ehlbeck J. and Schlüter, O., 2015. Impact of thermal treatment versus cold atmospheric plasma processing on the techno-functional protein properties from Pisum sativum 'Salamanca'. Journal of Food Engineering 167(Part B): 166-174. https://doi.org/10.1016/j.jfoodeng.2015.05.036

Cammack, J.A. and Tomberlin, J.K., 2017. The impact of diet protein and carbohydrate on select life-history traits of the black soldier fly Hermetia illucens (L.) (Diptera: Stratiomyidae). Insects 8: 1-14. https://doi.org/10.3390/insects8020056

Canadian Food Inspection Agency (CFIA), 2018. Food microbiology - targeted surveys: final report on bacterial pathogens in edible insects, from April 1, 2017 to March 30, 2018. SGDDI 10939446. Government of Canada, Ottawa, ON, Canada.

Canadian Food Inspection Agency (CFIA), 2019. Registration requirements for insect-derived livestock feed ingredients. Government of Canada, Ottawa, ON, Canada. Available at: https:// inspection.canada.ca/animal-health/livestock-feeds/consultations/ registration-requirements/eng/1557837434904/1557837435158

Caparros Megido, R., Desmedt, S., Blecker, C., Béra F., Haubruge, É., Alabi, T. and Francis, F., 2017. Microbiological load of edible insects found in Belgium. Insects 8: 12. https://doi.org/10.3390/ insects 8010012

Cappellozza, S., Leonardi, M.G., Savoldelli, S., Carminati, D., Rizzolo, A., Cortellino, G., Terova, G., Moretto, E., Badaile, A., Concheri, G., Saviane, A., Bruno, D., Bonelli, M., Caccia, S., Casartelli, M. and Tettamanti, G., 2019. A first attempt to produce proteins from insects by means of a circular economy. Animals 9(5): 278. https:// doi.org/10.3390/ani9050278 
Choi, Y.S., Choi, J.H., Han, D.J., Kim, H.Y., Lee, M.A., Kim, H.W., Jeong, J.Y. and Kim, C.J., 2009. Characteristics of low-fat meat emulsion systems with pork fat replaced by vegetable oils and rice bran fiber. Meat Science 82: 266-271. https://doi.org/10.1016/j. meatsci.2009.01.019

De Smet, J., Wynants, E., Cos, P. and Van Campenhout, L., 2018. Microbial community dynamics during rearing of black soldier fly larvae (Hermetia illucens) and impact on exploitation potential. Applied and Environmental Microbiology 84(9): e02722-17. https:// doi.org/10.1128/AEM.02722-17

Faustman, C., Cassens, R.G., Schaefer, D.M., Buege, D.R., Williams, S.N. and Scheller, K.K., 1989. Improvement of pigment and lipid stability in Holstein steer beef by dietary supplementation with vitamin E. Journal of Food Science 54(4): 858-862. https://doi. org/10.1111/j.1365-2621.1989.tb07899.x

Geveke, D.J., 2008. UV inactivation of E. coli in liquid egg white. Food and Bioprocess Technology 1(2): 201-206. https://doi.org/10.1007/ s11947-008-0070-1

Gill, C.O., 2000. HACCP in primary processing: red meat. In: Brown, M. (ed.) HACCP in the meat industry. CRC Press, Boca Raton, FL, USA, pp. 81-122. https://doi.org/10.1533/9781855736443.2.81

Gold, M., Tomberlin, J.J.K., Diener, S., Zurbrügg, C. and Mathys, A., 2018. Decomposition of biowaste macronutrients, microbes, and chemicals in black soldier fly larval treatment: a review. Waste Management 82: 302-318. https://doi.org/10.1016/j. wasman.2018.10.022

Gold, M., Von Allmen, F., Zurbrügg, C., Zhang, J. and Mathys, A., 2020. Identification of bacteria in two food waste black soldier fly larvae rearing residues. Frontiers in Microbiology 11: 582867. https://doi.org/10.3389/fmicb.2020.582867

Grabowski, N.T. and Klein, G., 2017. Bacteria encountered in raw insect, spider, scorpion, and centipede taxa including edible species, and their significance from the food hygiene point of view. Trends in Food Science \& Technology 63: 80-90. https://doi.org/10.1016/j. tifs.2017.01.007

Grau, A., Codony, R., Rafecas, M., Barroeta, A.C. and Guardiola, F., 2000. Lipid hydroperoxide determination in dark chicken meat through a ferrous oxidation - xylenol orange method. Journal of Agricultural and Food Chemistry 48: 4136-4143. https://doi. org/10.1021/jf991054z

Health Canada, 1997. Determination of Enterobacteriaceae, MFLP-43. The compendium of analytical methods. Vol. 3. Health Canada, Ottawa, ON, Canada. Available at: https://www.canada.ca/en/ health-canada/services/food-nutrition/research-programs-

analytical-methods/analytical-methods/compendium-methods.html

Health Canada, 2001a. Determination of the aerobic colony count of foods, MFHPB-18. The compendium of analytical methods. Vol. 2. Health Canada, Ottawa, ON, Canada. Available at: https://www.canada. ca/en/health-canada/services/food-nutrition/research-programsanalytical-methods/analytical-methods/compendium-methods.html

Health Canada, 2001b. Determination of coliforms in foods using Violet Red Bile Agar, MFHPB-31. The compendium of analytical methods. Vol. 2. Health Canada, Ottawa, ON, Canada. Available at: https:// www.canada.ca/en/health-canada/services/food-nutrition/researchprograms-analytical-methods/analytical-methods/compendiummethods.html
Health Canada, 2009. Isolation and identification of Salmonella from food and environmental samples, MFHPB-20. The compendium of analytical methods. Vol. 2. Health Canada, Ottawa, ON, Canada. Available at: https://www.canada.ca/en/health-canada/services/ food-nutrition/research-programs-analytical-methods/analyticalmethods/compendium-methods.html

Health Canada, 2011. Isolation of Listeria monocytogenes and other Listeria spp. from foods and environmental samples, MFHPB-30. The compendium of analytical methods. Vol. 2. Health Canada, Ottawa, ON, Canada. Available at: https://www.canada.ca/en/ health-canada/services/food-nutrition/research-programs-

analytical-methods/analytical-methods/compendium-methods.html

Health Canada, 2013. Enumeration of Escherichia coli and coliforms in food products and food ingredients using $3 \mathrm{M}^{\mathrm{mm}}$ Petrifilm ${ }^{\mathrm{Tm}}$ E. coli count plates, MFHPB-34. The compendium of analytical methods. Vol. 2. Health Canada, Ottawa, ON, Canada. Available at: https:// www.canada.ca/en/health-canada/services/food-nutrition/researchprograms-analytical-methods/analytical-methods/compendiummethods.html

Health Canada, 2018. Enumeration of yeasts and moulds in food, MFHPB-22. The compendium of analytical methods. Vol. 2. Health Canada, Ottawa, ON, Canada. Available at: https://www.canada. ca/en/health-canada/services/food-nutrition/research-programsanalytical-methods/analytical-methods/compendium-methods.html

Heath, J.L., 1977. Chemical and related osmotic changes in egg albumen during storage. Poultry Science 56(3): 822-828. https:// doi.org/10.3382/ps.0560822

Hermes-Lima, M., Willmore, W.G. and Storey, K.B., 1995. Quantification of lipid peroxidation in tissue extracts based on Fe(III) xylenol orange complex formation. Free Radical Biology \& Medicine 19: 271-280. https://doi.org/10.1016/0891-5849(95)00020-X

Hogsette, J.A., 1992. New diets for production of house-flies and stable flies (Diptera, Muscidae) in the laboratory. Journal of Economic Entomology 85: 2291-2294. https://doi.org/10.1093/jee/85.6.2291

Hosseinpour, S., Rafiee, S., Mohtasebi, S.S. and Aghbashlo, M., 2013. Application of computer vision technique for on-line monitoring of shrimp color changes during drying. Journal of Food Engineering 115(1): 99-114. https://doi.org/10.1016/j.jfoodeng.2012.10.003

Huang, C., Feng, W., Xiong, J., Wang, T., Wang, W., Wang, C. and Yang, F., 2019. Impact of drying method on the nutritional value of the edible insect protein from black soldier fly (Hermetia illucens L.) larvae: amino acid composition, nutritional value evaluation, in vitro digestibility, and thermal properties. European Food Research and Technology 245(1): 11-21. https://doi.org/10.1007/s00217018-3136-y

Janssen, R.H., Canelli, G., Sanders, M.G., Bakx, E.J., Lakemond, C.M.M., Fogliano, V. and Vincken, J.-P., 2018. Iron-polyphenol complexes cause blackening upon grinding Hermetia illucens (black soldier fly) larvae. Nature Scientific Reports 9: 2967. https://www. nature.com/articles/s41598-019-38923-x

Janssen, R.H., Vincken, J.P., Van den Broek, L.A., Fogliano, V. and Lakemond, C.M., 2017. Nitrogen-to-protein conversion factors for three edible insects: Tenebrio molitor, Alphitobius diaperinus, and Hermetia illucens. Journal of Agricultural and Food Chemistry 65(11): 2275-2278. https://doi.org/10.1021/acs.jafc.7b00471 
Jay, J.M., 1992. Modern food microbiology, $4^{\text {th }}$ edition. Chapman \& Hall, New York, NY, USA, 701 pp.

Joanisse, D.R. and Storey, K.B., 1998. Oxidative stress and antioxidants in stress and recovery of cold-hardy insects. Insect Biochemistry and Molecular Biology 28(1): 23-30. https://doi.org/10.1016/S09651748(97)00070-2

Joubran, Y., Moscovici, A. and Lesmes, U., 2015. Antioxidant activity of bovine alpha lactalbumin Maillard products and evaluation of their in vitro gastro-duodenal digestive proteolysis. Food \& Function 6(4): 1229-1240. https://doi.org/10.1039/c4fo01165a

Kamau, E., Mutungib, C., Kinyuru, J., Imathiu, S., Tanga, C., Affognon, H., Ekesi, S., Nakimbugwe, D. and Fiaboe, K.K.M., 2018. Moisture adsorption properties and shelf-life estimation of dried and pulverised edible house cricket Acheta domesticus (L.) and black soldier fly larvae Hermetia illucens (L.). Food Research International 106: 420-427. https://doi.org/10.1016/j.foodres.2018.01.012

Kashiri, M., Marin, C., Garzon, R., Rosell, C.M., Rodrigo, D. and Martinez, A., 2018. Use of high hydrostatic pressure to inactivate natural contaminating microorganisms and inoculated E. coli O157:H7 on Hermetia illucens larvae. PLoS ONE 13(3): e0194477. https://doi.org/10.1371/journal.pone.0194477

Ketata, M., Desjardins, Y. and Ratti, C., 2013. Effect of liquid nitrogen pre-treatments on osmotic dehydration of blueberries. Journal of Food Engineering 116(1): 202-212. https://doi.org/10.1016/j. jfoodeng.2012.10.035

Klammsteiner, T., Walter, A., Bogataj, T., Heussler, C.D., Stres, B., Steiner, F.M., Schlick-Steiner, B.C., Arthofer, W. and Insam, H., 2020. The core gut microbiome of black soldier fly (Hermetia illucens) larvae raised on low-bioburden diets. Frontiers in Microbiology 11: 1-14. https://doi.org/10.3389/fmicb.2020.00993

Klunder, H.C., Wolkers-Rooijackers, J., Korpela, J.M. and Nout, M.J.R., 2012. Microbiological aspects of processing and storage of edible insects. Food Control 26(2): 628-631. https://doi.org/10.1016/j. foodcont.2012.02.013

Koniecko, E.S., 1984. Handbook of meat analysis, $2^{\text {nd }}$ edition. Avery Pub Group, New York, NY, USA, 289 pp.

Lalander, C., Diener, S., Zurbrügg, C. and Vinnerås, B., 2019. Effects of feedstock on larval development and process efficiency in waste treatment with black soldier fly (Hermetia illucens). Journal Cleaner Production 208: 211-219. https://doi.org/10.1016/j. jclepro.2018.10.017

Lang, E., Zoz, F., Iaconelli, C., Guyot, S., Alvarez-Martin, P., Beney, L., Perrier-Cornet, J.-M. and Gervais, P., 2016. Recovery estimation of dried foodborne pathogens is directly related to rehydration kinetics. PLoS ONE 11(8): e0160844. https://doi.org/10.1371/ journal.pone.0160844

Larouche, J., 2019. Processing methods for the black soldier fly (Hermetia illucens) larvae: From feed withdrawal periods to killing methods. Université Laval, Quebec City, Québec, Canada, 86 pp. Available at: https://corpus.ulaval.ca/jspui/ handle/20.500.11794/37923

Larouche, J., Deschamps, M.-H., Saucier, L., Lebeuf, Y., Doyen, A. and Vandenberg, G.W., 2019. Effects of killing methods on lipid oxidation, colour and microbial load of black soldier fly (Hermetia illucens) larvae. Animals 9: 182. https://doi.org/10.3390/ani9040182
Marshall, D.L. and Bal'a, M.F.A., 2001. Microbiology of meat. In: Hui, Y.H., Nip, W.K. and Rogers, R. (eds.) Meat science and applications. Marcel Dekker, Inc, New York, NY, USA, pp. 160-181.

Melgar-Lalanne, G., Hernández-Álvarez, A.J. and Salinas-Castro, A., 2019. Edible insects processing: traditional and innovative technologies. Comprehensive Reviews in Food Science and Food Safety 18(4): 1166-1191. https://doi.org/10.1111/1541-4337.12463 Minister of Justice of Canada, 2021. Feeds regulations, 1983 (SOR/83593), Schedule IV. Legislation Revision and Consolidation Act. Government of Canada, Ottawa, ON, Canada. Available at: https:// laws-lois.justice.gc.ca/eng/regulations/SOR-83-593/page-11.html

Ministère de l'agriculture des pêcheries et de l'alimentation du Québec (MAPAQ), 2019. Lignes directrices et normes pour l'interprétation des résultats analytiques en microbiologie alimentaire. Gouvernement du Québec, Québec, QC, Canada, 58 pp.

Nesvadba, P., 2014. Thermal properties of unfrozen foods. In: Rao, M., Rizvi, S., Datta, A. and Ahmed, J. (eds.) Engineering properties of foods, $4^{\text {th }}$ edition. CRC Press, Boca Raton, FL, USA, pp. 223-246. https://doi.org/10.1201/b16897

Nguyen, T.T.X., Tomberlin, J.K. and Vanlaerhoven, S., 2013. Influence of resources on Hermetia illucens (Diptera: Stratiomyidae) larval development. Journal of Medical Entomology 50: 898-906. https:// doi.org/10.1603/ME12260

Nowak, V., Persijn, D., Rittenschober, D. and Charrondiere, U.R., 2016. Review of food composition data for edible insects. Food Chemistry 193: 39-46. https://doi.org/10.1016/j.foodchem.2014.10.114

Purriños, L., Bermúdez, R., Franco, D., Carballo, J. and Lorenzo, J.M., 2011. Development of volatile compounds during the manufacture of dry-cured 'Lacón,' a Spanish traditional meat product. Journal of Food Science 76: C89-C97. https://doi.org/10.1111/j.17503841.2010.01955.x

Purschke, B., Brüggen, H., Scheibelberger, R. and Jäger, H., 2018. Effect of pre-treatment and drying method on physico-chemical properties and dry fractionation behaviour of mealworm larvae (Tenebrio molitor). European Food Research and Technology 244(2): 269-280. https://doi.org/10.1007/s00217-017-2953-8

Rahman, M.S., 2007. Food preservation: an overview. In: Rahman, M.S. (ed.) Handbook of food preservation, part A: preservation of fresh food products. CRC Press, Boca Raton, FL, USA, pp. 3-17.

Ratti, C., 2001. Hot air and freeze-drying of high-value foods: a review. Journal of Food Engineering 49(4): 311-319. https://doi.org/10.1016/ S0260-8774(00)00228-4

Ratti, C., 2010. Freeze-drying process design. In: Ahmed, J. and Rahman, M.S. (eds.) Handbook of food process design. John Wiley \& Sons Inc., New York, USA, pp. 621-647. https://doi. org/10.1002/9781444398274

Rumpold, B.A. and Schlüter, O.K., 2013a. Nutritional composition and safety aspects of edibles insects. Molecular Nutrition Food Resources 57: 802-823. https://doi.org/10.1002/mnfr.201200735

Rumpold, B.A. and Schlüter, O.K., 2013b. Potential and challenges of insects as an innovative source for food and feed production. Innovative Food Science and Emerging Technologies 17: 1-11. https://doi.org/10.1016/j.ifset.2012.11.005

Saucier, L., Gendron, C. and Gariépy, C., 2000. Shelf life of ground poultry meat stored under modified atmosphere. Poultry Science 79: 1851-1856. https://doi.org/10.1093/ps/79.12.1851 
Shelomi, M., Wu, M.-K., Chen, S.-M., Huang, J.-J. and Burke C.G., 2020. Microbes associated with black soldier fly (Diptera: Stratiomyidae) degradation of food waste. Environmental Entomology 49: 405-411. https://doi.org/10.1093/ee/nvz164

Sun-Waterhouse, D., Waterhouse, G.I.N, You, L., Zhang, J., Liu, Y., Ma, L., Gao, J. and Dong, Y., 2016. Transforming insect biomass into consumer wellness foods: a review. Food Research International 89(1): 129-151. https://doi.org/10.1016/j.foodres.2016.10.001

Tanga, C.M., Waweru, J.W., Tola, Y.H., Onyoni, A.A., Khamis, F.M., Ekesi, S. and Paredes, J.C., 2021. Organic waste substrates induce important shifts in gut microbiota of black soldier fly (Hermetia illucens $L$.): coexistence of conserved, variable, and potential pathogenic microbes. Frontiers in Microbiology 12: 635881. https:// doi.org/10.3389/fmicb.2021.635881

Uchiyama, M. and Mihara, M., 1978. Determination of malonaldehyde precursor in tissues by thiobarbituric acid test. Analytical Biochemistry 86: 271-278. https://doi.org/10.1016/00032697(78)90342-1

Ursu, A.V., Marcati, A., Michaud, P. and Djelveh, G., 2016. Valorisation of industrial cooked ham by-products as functional ingredients. Journal of Food Engineering 190: 54-60. https://doi.org/10.1016/j. jfoodeng.2016.06.013

Valeras, V., 2019. Food wastes as a potential new source for edible insect mass production for food and feed: a review. 2019. Fermentation 5(3): 81. https://doi.org/10.3390/fermentation5030081

Van Huis, A., 2013. Potential of Insects as food and feed in assuring food security. Annual Review of Entomology 58: 563-583. https:// doi.org/10.1146/annurev-ento-120811-153704.

Van Huis, A., Van Itterbeeck, J., Klunder, H., Mertens, E., Halloran, A., Muir, G. and Vantomme, P., 2013. Edible insects: future prospects for food and feed security. FAO Forestry paper no. 171. Food and Agriculture Organisation, Rome, Italy. Available at: http://www. fao.org/3/i3253e/i3253e.pdf
Vandeweyer, D., Lenaerts, S., Callens, A. and Van Campenhout, L., 2017. Effect of blanching followed by refrigerated storage or industrial microwave drying on the microbial load of yellow mealworm larvae (Tenebrio molitor). Food Control 71: 311-314. https://doi.org/10.1016/j.foodcont.2016.07.011

Vega-Mercado, H., Gongora-Nieto, M. and Barbosa-Canovas, G.V., 2001. Advances in dehydration of foods. Journal of Food Engineering 49(4): 271-289. https://doi.org/10.1016/S0260-8774(00)00224-7

Viera-Alves, A., Sanjinez-Argandõna, E.J., Linzmeier, A.M., Cardoso, C.A.L. and Macedo, M.L.R., 2016. Food value of mealworm grown on Acrocomia aculeata. pulp flour. PLoS ONE 11(3): e0151275. https://doi.org/10.1371/journal.pone.0151275

Wynants, E., Frooninckx, L., Crauwels, S., Verreth, C., De Smet, J., Sandrock C., Wohlfahrt, J., Van Schelt, J., Depraetere, S., Lievens, B., Van Miert, S., Claes, J. and Van Campenhout, L., 2019. Assessing the microbiota of black soldier fly larvae (Hermetia illucens) reared on organic waste streams on four different locations at laboratory and large scale. Microbial Ecology 77(4): 913-930. https://doi. org/10.1007/s00248-018-1286-x

Yang, F., Tomberlin, J.K. and Jordan, H.R., 2021. Starvation alters gut microbiome in black soldier fly (Diptera: Stratiomyidae) larvae. Frontiers in Microbiology 12: 601253. https://doi.org/10.3389/ fmicb.2021.601253

Yi, G., Haug, A., Nyquist, N.F. and Egelandsdal, B., 2013. Hydroperoxide formation in different lean meats. Food Chemistry 141: 2656-2665. https://doi.org/10.1016/j.foodchem.2013.05.041

Zar, J.H., 1999. Biostatistical analysis, $4^{\text {th }}$ edition. Prentice-Hall, Upper Saddle River, NJ, USA, 663 pp.

Zhen, Y., Chundang, P., Zhang, Y., Wang, M., Vongsangnak, W., Pruksakorn, C. and Kovitvadhi, A., 2020. Impacts of killing process on the nutrient content, product stability and in vitro digestibility of black soldier fly (Hermetia illucens) larvae meals. Applied Science 10: 6099. https://doi.org/10.3390/app10176099

Zurbrügg, C., Dortmans, B., Fadhila, A., Verstappen, B. and Diener, S., 2018. From pilot to full scale operation of a waste-to-protein treatment facility. Detritus 1: 18-22. https://doi.org/10.264.03/ detritus/2018.22 